$$
\text { UNIVERSIDADE DE SÃO PAULO }
$$

Faculdade de Filosofia, Letras e Ciências Humanas

Departamento de História

Programa de Pós-Graduação em História Social

\title{
HISTÓRIA, POLÍTICA E REVOLUÇÃO EM ERIC HOBSBAWM E FRANÇOIS FURET
}

\author{
Priscila Gomes Correa
}

São Paulo

2006 
UNIVERSIDADE DE SÃO PAULO

Faculdade de Filosofia, Letras e Ciências Humanas

Departamento de História

Programa de Pós-Graduação em História Social

\section{HISTÓRIA, POLÍTICA E REVOLUÇÃO EM ERIC HOBSBAWM E FRANÇOIS FURET}

Priscila Gomes Correa

Dissertação apresentada ao Programa de PósGraduação em História Social, do Departamento de História da Faculdade de Filosofia, Letras e Ciências Humanas da Universidade de São Paulo, para obtenção do título de Mestre.

Orientador: Prof. Dr. Modesto Florenzano 
Meus sinceros agradecimentos

aos meus pais e irmãos, pelo apoio incondicional;

aos amigos, em especial, à Marina Scalabrini, pelas leituras e comentários sempre otimistas;

ao meu orientador, o professor Modesto Florenzano;

E, finalmente, agradeço à Fundação de Amparo à Pesquisa do Estado de São Paulo (FAPESP), cujo auxílio foi fundamental para a realização deste trabalho. 


\title{
Resumo
}

Nesta dissertação pretendemos realizar um estudo comparativo entre Eric Hobsbawm e François Furet, dois importantes historiadores do século XX, com trajetórias intelectuais opostas que, no entanto, convergiram para a interpretação das relações entre história, política e revolução. Tomamos como fonte documental seus trabalhos historiográficos, com o intuito de refletir sobre a relação entre o pensamento histórico e o pensamento político. Assim, situando o problema da relação entre o intelectual e a política, buscamos, por meio da análise historiográfica e do exercício sistemático de comparação e confrontação, abordar os participantes do debate historiográfico/político como atores históricos, visto que atuando em uma diversidade de culturas políticas e tradições de pensamento.

\begin{abstract}
Our goal in this dissertation is to compare the works of two twentieth century historians - Eric Hobsbawm and François Furet - analysing their different intellectual trajectories and their interpretation of the relationship between history, politics and revolution. The documentary source used in this study consists mainly of their historiographical works. In this way, by an historiographical analysis and by a systematic comparation and confrontation of their works, we have approached the debate that results from the different and contrasting political culture and ideological thought present in both as historical actors.
\end{abstract}

\section{Palavras-chave I Key words}

Historiografia - Século XX - Revolução - Marxismo - Comunismo

Historiography - XX Century - Revolution - Marxism - Communism 
SUMÁRIO 


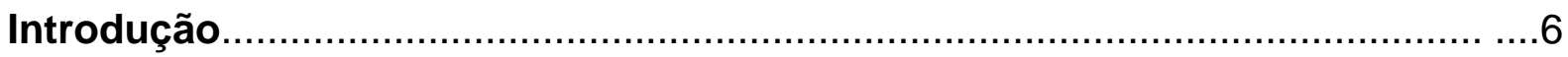

- Uma Confrontação Possível................................................................

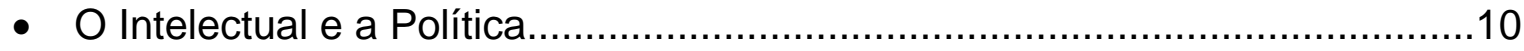

- História Intelectual e Historiografia..............................................................17

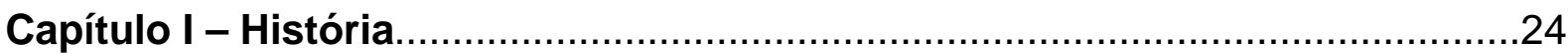

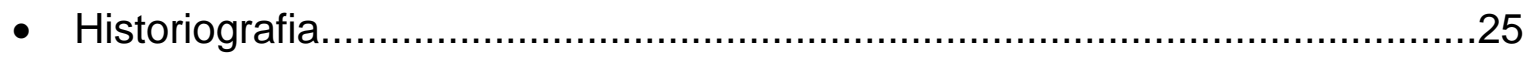

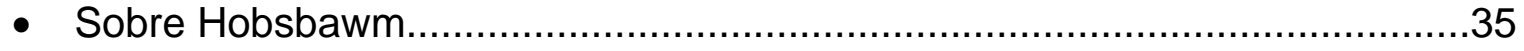

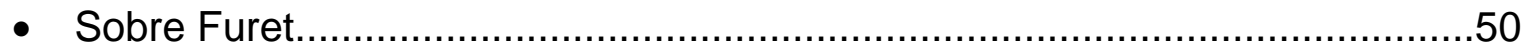

- História: de disciplina à ciência......................................................64

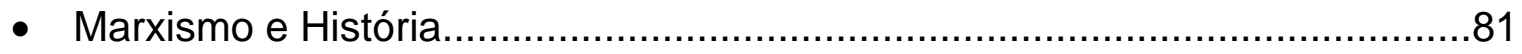

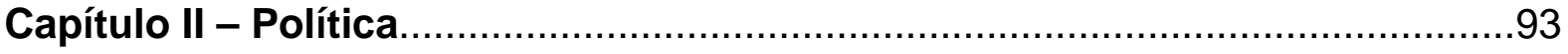

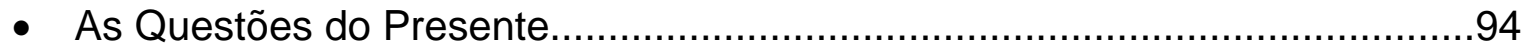

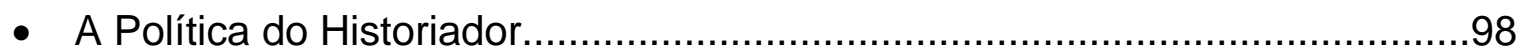

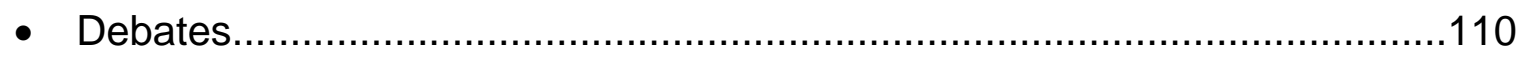

- Século XX: história e interpretação......................................................114

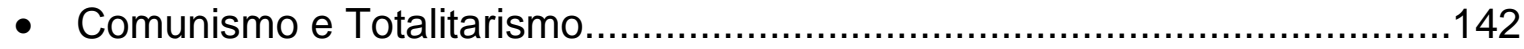

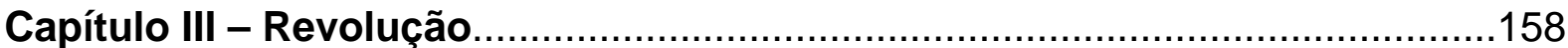

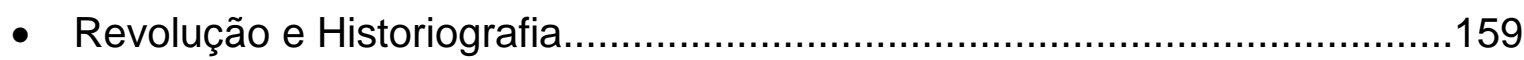

- Uma revolução "largamente burguesa e democrática" ..............................177

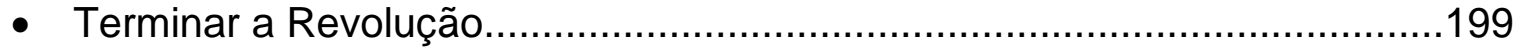

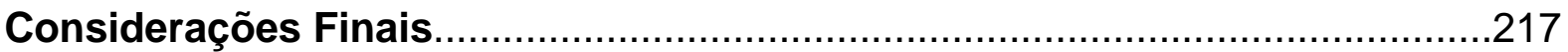

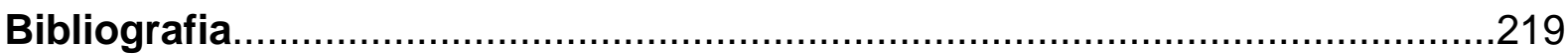

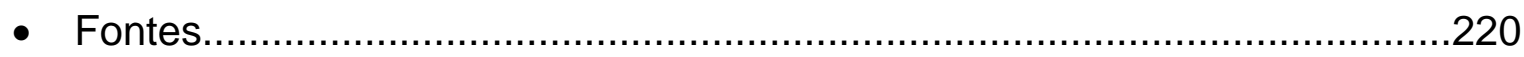

- Levantamento bibliográfico - Eric Hobsbawm.......................................221

- Levantamento bibliográfico - François Furet..........................................225

• Obras de Referência......................................................................232 


\section{INTRODUÇÃO}

"Viram, portanto, pela aproximação de citações e de fórmulas precisas, como espíritos diferentes, partindo dos mesmos dados, exercendo as suas virtudes críticas e seus talentos de organização imaginativa sobre os mesmos documentos - e aliás animados (espero) por um desejo idêntico de encontrar a verdade - , dividem-se, entretanto, opõem-se, repelem-se quase tão ferozmente quanto facções políticas”.

Paul Valéry - 1932 


\section{Uma Confrontação Possível}

Em seu “Discurso sobre a História”, Paul Valéry expôs uma curiosa constatação: “em épocas normais, a guilhotina felizmente não está à disposição dos historiadores”. ${ }^{1}$ Metáfora pertinente porém incômoda, pois destaca entre as convicções dos historiadores suas vontades e o poder de sua autoridade expressa pela opinião, decorrendo em divergências e disputas que visam o “extermínio do adversário”. Sobrevém, ainda, a nítida idéia da história como mero resultado de opiniões dominantes, assemelhando-se às proposições dos políticos que vencem os escrutínios. Eis um transtorno que de tempos em tempos aflige os historiadores, coloca-se em questão não só a ciência como também a disciplina. ${ }^{2}$ Podemos amenizar a questão se àquela constatação opormos, ou melhor, acrescentarmos que, apesar desses inevitáveis confrontos, o historiador terá, sempre, na pauta de suas proposições, a responsabilidade social de seu ofício. Ademais, é por essa responsabilidade que se tramam os debates historiográficos, via aberta para o historiador fazer-se intelectual, uma figura ativa na sociedade.

Nesse complexo e controverso nicho encontraremos Eric Hobsbawm e François Furet, historiadores que, durante o século XX, concentraram-se nas relações entre história, política e revolução. Suas posturas ideológicas são sabidamente opostas, representam tradições diferentes de interpretação historiográfica e política, mas não podem ser simplesmente alocadas em “famílias” intelectuais, pois cada um guarda, entre intertextos e contextos, a originalidade própria de suas obras e trajetórias. Em outras palavras, não estamos diante de dois personagens exemplares de tendências historiográficas ou intelectuais, mas sim influentes, e cuja consagração se evidenciou entre o grande público. As relações entre pertença e especificidade, entre trajetórias intelectuais e historiografia, entre política e história, entre diferenças e semelhanças, constituem a base deste estudo comparativo, favorecendo a elucidação de grandes temas da historiografia por meio dos olhares minuciosos desses dois historiadores.

\footnotetext{
${ }^{1}$ Valéry, P. Variedades. São Paulo, Iluminuras, 1991, p.115.

${ }^{2}$ Neste sentido, podemos citar a avaliação de Lawrence Stone acerca da controvérsia dos historiadores ingleses sobre o caráter social da Revolução Inglesa: "Em primeiro lugar o terreno do desacordo parecia ser o mais abrangente possível: desacordo sobre a definição dos termos usados para explicar os fenômenos em questão; desacordo sobre o que aconteceu; desacordo sobre como aconteceu; desacordo sobre as conseqüências do que aconteceu. Uma tal ausência de terreno comum é verdadeiramente rara, e sua manifestação pareceu colocar em dúvida o direito do historiador de ser visto como um pesquisador empírico que fundamenta sua investigação sobre a razão e a prova”. Stone, L. Causas da Revolução Inglesa, 1529-1642. Bauru:SP, EDUSC, 2000. p.78.
} 
Com trajetórias intelectuais marcadas pelo posicionamento político, Eric Hobsbawm (um comunista) e François Furet (um anticomunista), engajaram-se na compreensão de seu “presente”, desenvolvendo estudos históricos em paralelo com reflexões sobre a sociedade contemporânea. Eminente estudioso da história mundial e de movimentos populares, Hobsbawm se tornou um dos principais representantes daquela que se conhece como a historiografia marxista britânica; não obstante sua inegável influência, seu trabalho não motivou a formação de escola, mas arrebanhou um amplo consenso. Furet, ao contrário, tornou-se o principal representante de um grupo de historiadores liberais (geralmente anticomunistas) que se dedicaram à realização de uma verdadeira revisão da historiografia revolucionária francesa; na década de oitenta, foi aclamado como o maitre à penser da historiografia da Revolução Francesa, tendo sua interpretação conquistado, nas últimas décadas, uma verdadeira hegemonia.

Estamos diante de dois intelectuais, com todas as nuances que o conceito abriga, atores históricos que nos colocaram o problema da relação entre o pensamento histórico e o pensamento político. Problema que surge no interior de seus trabalhos historiográficos, e cujo esclarecimento buscamos ao contrapor a Era dos Extremos de Hobsbawm e O Passado de uma Ilusão de Furet, obras sobre o século XX que coroaram suas carreiras e representaram um passo decisivo em seus estudos sobre o acontecimento revolucionário, em especial, sobre a Revolução Francesa, foco de indagações pontuais em parte do conjunto de suas obras. O paralelo se completa com seus estudos sobre a própria Revolução Francesa (em A Era das Revoluções e Ecos da Marselhesa no caso de Hobsbawm, e em A Revolução Francesa e Pensando a Revolução Francesa no caso de Furet), e sobre a História (em Sobre História de Hobsbawm e Oficina da História de Furet).

Como veremos, para analisar estas fontes atuamos na confluência entre historiografia e história intelectual, tendo em vista que a complexidade do tema reside, sobretudo, na relação história-política-revolução. Um pressuposto temático que por si só organizou as principais esferas de reflexão que apresentamos na ordenação dos capítulos. Todavia, a separação entre os temas é apenas instrumental, uma forma de esquematizar a exposição, uma vez que dissimula um emaranhado de entrelaçamentos entre os temas. Ao analisar o conjunto das obras de Hobsbawm e de Furet percebemos que suas reflexões não possuem uma evolução linear, compõem-se de avanços e recuos. Nem sempre seus trabalhos foram independentes, além das tradições de pensamento, há muito de culturas intelectuais e até nacionais. Nem 
sempre o contexto exerceu influência decisiva sobre suas proposições, pois além da responsabilidade do oficio, há muito do gênio pessoal de cada um. Poderíamos seguir com estas ressalvas, mas convém acompanhá-las no decorrer deste estudo, eliminando-se o risco de simplificações e de generalizações imprecisas.

No primeiro capítulo (História) identificamos a cultura histórica sob a qual atuaram Hobsbawm e Furet, ou seja, os traços da historiografia de onde partiram para a composição de suas trajetórias intelectuais e de suas respectivas concepções de história. O cerne do capítulo é a análise documental de Sobre Historia e A Oficina da História, desembocando numa investigação acerca das relações entre história e marxismo em seus trabalhos. O segundo capítulo (Política) consiste no miolo do trabalho, pois nele é explorada efetivamente a relação entre história e política, discutindo-se, em seguida, as principais questões quanto ao século XX pelo confronto entre a Era dos Extremos e O Passado de uma Ilusão (obras centrais que reúnem as três funções de nosso pressuposto temático: história, política e revolução). Nesse capítulo o intelectual e a política se encontram no debate acerca da situação política da Inglaterra e da França em fins da década de setenta, bem como pelas controvérsias que envolveram a questão do totalitarismo.

Ao acompanhar as trajetórias intelectuais de Hobsbawm e de Furet, defrontamo-nos, freqüentemente, com a questão da revolução; desenvolvemos a percepção de que a reflexão de ambos sobre esse fenômeno não motivou apenas seus estudos sobre os acontecimentos revolucionários, mas suas concepções sobre história e, sobretudo, suas interpretações sobre o desenrolar da história e da política no século XX; em outros termos, foi o tecido sobre o qual se fez a relação entre o historiador e seus objetos. Diante disso, a partir do tema da revolução refletimos acerca das fundações sobre as quais se encadearam história, política e revolução nas trajetórias e pensamentos dos dois historiadores, ou seja, o processo de elaboração dos materiais pertinentes à comparação. Tema tratado no terceiro capítulo (Revolução), onde foram cotejados os seguintes documentos: A Era das Revoluções/Ecos da Marselhesa e A Revolução Francesa/Pensando a Revolução Francesa. Além disso, é importante frisar que, para iluminar alguns elementos discursivos implícitos nas fontes, apresentamos no decorrer dos capítulos investigações subliminares sobre outros trabalhos de Hobsbawm e de Furet.

Assim, tivemos a ambição de tentar expor a tridimensionalidade da relação históriapolítica-revolução, escopo de difícil percepção em trabalhos expositivos ou analíticos. Por isso, a antevisão e revisão acompanharam o destrinchar de cada um dos capítulos; 
historiografia e história intelectual com a agravante, feliz, da comparação. Entrelaçar dois universos tão ricos, ora distintos ora idênticos, como os de Hobsbawm e Furet, mostrou como as comparações podem revelar problemas de fundo da análise historiográfica. Ao longo deste texto há encontros e desencontros entre cada um desses atores históricos, os quais requerem pontos de vista diferenciados para, em determinados momentos, poderem tocar-se. A confrontação é, portanto, possível e necessária. Exige uma série de cuidados, visto que as polêmicas conceituais, as evidências e segredos do discurso historiográfico e, sobretudo, a atualidade ideológica do tema, são elementos inerentes a este tipo de investigação e podem levar a labirintos sem saída. Por isso, buscamos expor com antecedência os pressupostos teóricos e metodológicos, mas só na medida em que afetassem a interpretação, pois nem todos os conceitos e idéias podem ser discutidos em sua diversidade de sentidos ideológicos.

\section{O Intelectual e a Política}

Situarmos o problema da relação entre o intelectual e a política foi o primeiro passo para elaborarmos um método adequado para lidar com os documentos selecionados. O locus deste estudo é a questão da política no pensamento historiográfico, por conseguinte, cabe lembrar que o conceito de política está ligado ao de poder e, neste caso, o poder ideológico que se exerce sobre as mentes pela produção e transmissão de idéias, de símbolos, de visões de mundo e de ensinamentos práticos mediante o uso da palavra ${ }^{3}$. Como sabemos, o historiador é um intelectual investido de uma certa autoridade e, conseqüentemente, a política está presente em seu discurso histórico, mas como destacou Norberto Bobbio trata-se de uma política própria da cultura e, por se realizar no longo prazo, não coincide com a política dos políticos. ${ }^{4}$ A definição é simples, porém não destituída de problemas, defrontamo-nos com um certo intelectual, com uma certa política, com um certo historiador, enfim com a duvidosa relação entre conhecimento e poder.

De fato, pressupomos Hobsbawm e Furet como intelectuais, mas o termo é complexo, resultado de determinados contextos culturais e de uma rica historiografia. A definição mais apurada de intelectual é certamente aquela desenvolvida na França a partir do caso Dreyfuss, em fins do século XIX, nascendo sob a égide da polêmica e do debate. Pascal Ory parte das

\footnotetext{
${ }^{3}$ Cf. Bobbio, N. Os intelectuais e o poder: dúvidas e opções dos homens de cultura na sociedade contemporânea. São Paulo, UNESP, 1997, p.15.

${ }^{4}$ Cf. Id., ibid., p. 102.
} 
primeiras acepções do termo, vinculadas ora a uma profissão ora a uma vocação, chegando a uma definição mais corrente, segundo a qual o intelectual não se definiria mais pelo que ele é, mas pelo que ele faz, por sua intervenção sobre o terreno do político, compreendido no sentido de debate sobre a cité. ${ }^{5} \mathrm{O}$ intelectual encarna, portanto, o espírito crítico e o faz pela intervenção, essencialmente política, nos assuntos da sociedade em que vive.

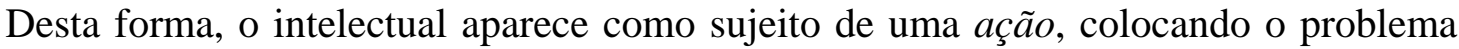
de seu papel e de seu poder. Um poder que lhe é outorgado pela sociedade, na medida em que ele se apresenta como um homem de cultura, criador ou mediador, fazendo-se, conseqüentemente, em homem de política, produtor e consumidor de ideologia. ${ }^{6}$ No entanto, não basta ser escritor, universitário, cientista ou artista para receber este poder. Segundo uma concepção desenvolvida pelos antidreyfusistes, identificada por Jean Paul Sartre, “o conjunto dos intelectuais aparece como uma variedade de homens que, tendo adquirido alguma notoriedade por trabalhos que dependem da inteligência (ciência exata, ciência aplicada, medicina, literatura, etc), abusam dessa notoriedade para sair de seu domínio e criticar a sociedade e os poderes estabelecidos em nome de uma concepção global e dogmática (vaga ou precisa, moralista ou marxista) do homem”. ${ }^{7}$ Nesta visão “original” o intelectual é aquele que se dedica a uma tarefa de intervenção política ou social sem que a isto seja chamado.

Ainda neste sentido podemos citar a “experiência intelectual” de Edgar Morin, para o qual ser intelectual "é autoinstituir-se como tal, quer dizer, atribuir-se uma missão: uma missão de cultura, uma missão contra o erro, uma missão de consciência pela humanidade”. 8 Para Morin ser intelectual é superar a profissão nas e pelas idéias, mas nesta definição o intelectual ainda aparece como aquele que se apropria de um espaço que não lhe é de direito, seria um deslocamento de seu reconhecimento profissional. Mas então de onde vem o seu poder, o reconhecimento de sua importância na sociedade? Já temos algumas pistas que apontam o intelectual como um produtor e transmissor de idéias, acrescente-se a isto que ele atua representativamente em nome de um sistema de valores. Nessa moralidade sua motivação pode tanto ser universalista quanto particularista e sua expressão é variada: são os ensaios, artigos, conferências, petições, etc, sempre abordando problemas humanos, morais, filosóficos ou políticos.

\footnotetext{
${ }^{5}$ Cf. Ory, P. et Sirinelli, J-P. Les intellectuels en France: de l'Affaire Dreyfus a nos jours. Paris, Armand Colin, 1992. p. 9

${ }^{6}$ Cf. Id., ibid., p. 10

7 Sartre, J-P. Em defesa dos intelectuais. São Paulo, Atica, 1994, p. 15.

${ }^{8}$ Morin, E. Os meus demônios. Portugal, Publicações Europa-América, 1995, p.189.
} 
No entanto, o reconhecimento profissional é um pressuposto para que ao intelectual seja atribuída de fato e de direito essa missão específica de cultura, eles acabam por representar as idéias, opiniões, visões de mundo de uma determinada época e de uma sociedade específica. Sob este aspecto Norberto Bobbio indicou um problema ancestral, o da relação entre política e cultura, visto que os intelectuais "mediante suas obras, eles também exercem um poder, embora por meio da persuasão”. ${ }^{9}$ Dessa relação Bobbio concluiu pela definição de "política da cultura", aquela própria dos intelectuais, sendo uma "ação que se enquadra bem numa concepção ampla de política, entendida como atividade voltada para a formação e a transformação da vida dos homens”. ${ }^{10}$ Em outros termos, para Bobbio os intelectuais possuem uma função política própria, o que garante a “autonomia relativa da cultura”. Neste sentido, essa abordagem aproxima-se da de Jean-François Sirinelli, para o qual o meio intelectual é o domínio do "metapolítico”, dos confrontos ideológicos, mais do que do político propriamente dito. ${ }^{11}$ É neste domínio, portanto, que o intelectual age por meio da palavra, ação que não deveria desembocar no falso problema do engajamento.

Eis uma questão muito premente em meados do século $\mathrm{XX}$, o verdadeiro intelectual deveria se engajar em sua função crítica, era "preciso contestar os próprios princípios da classe dominante”, dizia Sartre. Contudo, esta diretiva levava a suposição de que todo intelectual deveria ser de esquerda (radical), pois a única forma deste sujeito vencer a contradição que lhe é inerente entre sua técnica universalista e a ideologia dominante seria tomar para si o ponto de vista dos desfavorecidos. ${ }^{12}$ Por isso, nos últimos anos tem predominado a recusa da idéia de engajamento. Norberto Bobbio, por exemplo, destaca que é melhor utilizar o termo "responsabilidade”, “porque o que importa não é que o homem de cultura se engaje ou desengaje, e sim para que o faz, e que ele assuma, enfim, todas as responsabilidades por sua decisão e as conseqüências dela decorrentes”. ${ }^{13}$ Estas idéias de engajamento e de função crítica resultaram em relações ambíguas entre os intelectuais e o poder político durante o século XX, e, como veremos, a atividade política tanto de Hobsbawm quanto de Furet atingiu, em determinados momentos, este nebuloso limite entre a cultura e a política.

\footnotetext{
${ }^{9}$ Bobbio, N. O filósofo e a política: antologia. Rio de Janeiro, Contraponto, 2003, p.433.

${ }^{10}$ Id., ibid., p.490.

${ }^{11}$ Cf. Sirinelli, J-F. Os Intelectuais. In: Rémond, R. Por uma história política. Rio de Janeiro, UFRJ:FGV, 1996, p.261.

${ }^{12}$ Cf. Sartre, J-P. Op. cit., p.42.

${ }^{13}$ Bobbio, N. O filósofo e a política, op. cit., p.485.
} 
Entretanto, uma parte da interpretação de Sartre parece-nos adequada para este estudo, trata-se da sua idéia de contradição do intelectual. Este "técnico do saber” seria um homem diante da oposição "nele e na sociedade, entre a pesquisa da verdade prática (com todas as normas que ela implica) e a ideologia dominante (com seu sistema de valores tradicionais)”. 14 O intelectual surge, então, como produto histórico, atuando entre o universalismo de profissão e o particularismo de classe. Uma contradição presente, de certa forma, em Hobsbawm que, como sonhou Sartre, tentou se juntar a um movimento mais universal em prol das classes desfavorecidas. Mas, sobretudo na trajetória de Furet encontramos as possibilidades desta idéia, de comunista a liberal, ou seja, de “intelectual” a "falso intelectual”, como nos pesadelos de Sartre. É neste ponto que devemos abandonar a interpretação sartriana; François Furet, como veremos, foi um ativo homem de cultura, apesar de abandonar a idéia revolucionária e chegar a apostar num determinado status quo.

Ademais, essa idéia de contradição supõe que os intelectuais não se constituem em grupo autônomo acima das classes, o que nos permite fugir do "vício fundamental” apontado por Bobbio, que consiste em considerá-los desenraizados da sociedade em que vivem "ou pelo primado dos valores que representam ou pela superioridade intrínseca à sua vocação (ou profissão) de suscitadores de idéias diretivas”. ${ }^{15}$ Por outro lado, essa mesma noção de contradição carrega a possibilidade universalista e independente dos intelectuais, levando-nos a pensar, mais especificamente, em sua clientela. Somente em função desta faz sentido a representatividade do intelectual; não se trata, necessariamente, de seu grupo ou classe de origem, pois “a ausência de interesse ingênuo, de classe ou de outro tipo de grupo, é uma característica definidora dos intelectuais”, ${ }^{16}$ como bem destacou Ralf Dahrendorf ao discorrer sobre a responsabilidade pública dos intelectuais.

Dahrendorf, apoiado em Mannheim e Habermas, lembra que até recentemente não faltava aos intelectuais um público disposto a reivindicá-los como seus representantes, mas a tendência da sociedade a enfatizar elementos individuais no lugar das estruturas de região, religião ou classe os tem afastado do senso de responsabilidade pública. Um sintoma seria o crescente número de “comunidades científicas” fechadas sobre si mesmas, onde de biofísicos a historiadores "adquiriram o hábito de jogar seus jogos privados de revisionismo e

\footnotetext{
${ }^{14}$ Sartre, J-P. Op. cit., p.30.

${ }^{15}$ Bobbio, N. Os intelectuais e o poder, op. cit., p.36

${ }^{16}$ Dahrendorf, R. Após 1989: moral, revolução e sociedade civil. Rio de Janeiro, Paz e Terra, 1997, p.187.
} 
reconstrução”. ${ }^{17}$ Um exemplo disso, que abordamos no terceiro capítulo, é a tendência revisionista de interpretação da Revolução Francesa durante as comemorações do Bicentenário, a estratégia mais comum foi a suposta abstenção diante dos debates políticos e ideológicos, visto que o tema teria sofrido um “desinvestimento”, como anunciara anos antes François Furet. Este grupo de historiadores, também chamado de Escola Crítica, criou comunidades de trabalho em diversos países e produziu trabalhos coletivos onde o debate com outras tendências aparece como superado, tudo em resguardo de uma intenção "científica” dessas pesquisas.

Seguindo o argumento de Dahrendorf, pode-se dizer que este "comunitarismo" se revelou “quase uma questão de sobrevivência para representantes sem representados”, assim como os espaços nos meios de comunicação de massa, possibilitando aos intelectuais manifestar-se para um público difuso. ${ }^{18}$ No entanto, nesse ínterim o intelectual segue dissipando seu senso de responsabilidade universal ao adquirir uma suposta independência, agregando-se a equipes de pesquisadores especializados; a responsabilidade passa a ser, então, a do grupo. Os objetivos parecem mais nobres, sendo científicos, diante da ciência as contestações éticas perderiam o sentido, por conseguinte, o intelectual perderia seu antigo lugar. Esse conflito vem de longa data, seu ápice talvez tenha sido em meados do século passado, entre a ciência e a moral, diante da bomba atômica.

O debate segue vivo e é desnecessário aprofundar a discussão, desta devemos apreender que há uma responsabilidade pública do intelectual relativa, sobretudo, aos seus destinatários que estão no poder (político, social, econômico ou cultural). Como lembrou Bobbio, "a primeira tarefa dos intelectuais deve ser a de impedir que o monopólio da força se converta no monopólio da verdade”. ${ }^{19}$ Trata-se, com efeito, da relação entre a "política da cultura” e a "política dos políticos”, subjacente ao dilema entre conhecimento e poder. Em suma, são problemas inseparáveis da idéia de intelectual, bem como suas diversas classificações, se escribas, peritos ou literatos (Aron), se ideólogos ou especialistas (Bobbio), distinções que não convém abordarmos aqui. Este estudo está balizado pela forma como Hobsbawm e Furet enfrentaram tais problemas, e pelos papéis intelectuais de que se valeram

\footnotetext{
${ }^{17}$ Id., ibid., p.182.

${ }^{18}$ Cf. Id., ibid., p.188.

${ }^{19}$ Bobbio, N. O filosofo e a política, op. cit., p.469.
} 
na prática. Evidentemente procuramos não julgá-los, se suas atitudes foram nobres ou indevidas, evitando confundir análise com proposta. ${ }^{20}$

Hobsbawm é um historiador que se fez intelectual desde seus primeiros trabalhos, paixão e projeto político motivaram sua preocupação constante com os problemas da sociedade contemporânea, suas opções intelectuais e mesmo suas escolhas historiográficas partiram do diálogo com a "esfera pública”. É um intelectual por ter se engajado na causa comunista por meio das idéias, por participar de grupos de discussões historiográficas e políticas, pela freqüência assídua nos jornais e revistas, por manifestar-se publicamente quanto aos rumos da política, cultura e economia de seu país e do mundo e, por fim, é um intelectual por assim ser consagrado pelo público. Com François Furet não foi diferente, se fez intelectual como toda uma geração de pensadores franceses, por meio da dúvida e da crítica, pela Resistência, pelo comunismo e posterior anticomunismo, pela participação política no poder e na cultura, pelas iniciativas editoriais e pela manifestação semanal em periódicos e, sobretudo, por tornar-se uma espécie de maître à penser, um líder intelectual.

Resta uma última questão, estamos diante de dois historiadores/intelectuais que, além de apresentarem visões de mundo e personalidades diferentes senão opostas, pertencem a culturas nacionais específicas. Não se trata de superestimar as pressões do contexto, mas de avaliar as inegáveis diferenças que existem entre os debates ideológicos de país a país. Ser intelectual na França, na Grã-Bretanha ou nos Estados Unidos é gozar de estatutos diferentes na sociedade, é compartilhar tradições de pensamento e culturas políticas específicas. Como veremos, tais conjunturas ligadas às trajetórias intelectuais de Hobsbawm e de Furet motivaram perspectivas diferentes de análise no decorrer deste trabalho. A questão dos “debates nacionais” está presente na historiografia dos intelectuais desde trabalhos clássicos como o de Raymond Aron, O Ópio dos Intelectuais de 1955 que, apesar de suas motivações ideológicas, apresentou um importante esboço da questão. ${ }^{21}$

O fato, identificado por Aron, é que na Grã-Bretanha os debates ideológicos relacionam-se com os conflitos presentes, enquanto que na França o pensamento político é

\footnotetext{
${ }^{20}$ Neste sentido: "Nem complacente, nem membro, a contrário, de qualquer pelotão de fuzilamento da história, o historiador dos intelectuais não tem como tarefa nem construir um Panteão, nem cavar uma fossa comum”. Sirinelli, J-F. Os Intelectuais. In Rémond, R. op cit., p.261.

${ }^{21}$ Bénedicte Delórme-Montini considera este trabalho de Aron uma determinante matriz da historiografia sobre os intelectuais, pois está situado no início de uma profunda mutação na história soviética e na posterior história dos intelectuais. Cf. Delórme-Montini, B. Intellectuels: um nouvel objet d'histoire. Le Débat, nº112, novembredecembre 2000, p.89. Esta obra inspirou, inclusive, o proeminente ensaio de Furet, O Passado de uma Ilusão.
} 
retrospectivo ou utópico, tendendo a descolar do presente. ${ }^{22}$ Uma generalização um tanto vaga, mas que pode ser fundamental, na medida em que na França, durante o século XX, a política concentrou-se essencialmente no antagonismo histórico entre direita e esquerda. $\mathrm{Na}$ Grã-Bretanha, por outro lado, esta oposição foi um fenômeno secundário, com o liberalismo e a democracia sendo encarados como uma obra comum de partidos rivais.O debate neste país tornou-se mais técnico do que ideológico, o que não impede, acrescenta Aron, que “os britânicos apresentem o mesmo leque de opiniões, a mesma galeria de intelectuais do resto da Europa. As diferenças maiores são relativas ao que está em jogo, alhures interroga-se sobre as escolhas a fazer, aqui sobre as escolhas dos outros". ${ }^{23}$

Outro exemplo, desses percursos diversos entre britânicos e franceses, é o lugar conquistado pelo marxismo; seu impacto foi muito forte na maioria dos partidos socialistas continentais, enquanto que nem o movimento sindical britânico foi por ele atraído. O papel dos partidos comunistas também foi muito desigual, na França representou uma potência política sem precedentes entre os intelectuais da geração de François Furet, ao passo que o comunismo inglês sempre foi frágil, um fenômeno marginal. Isto talvez explique uma parte da ferrenha oposição intelectual enfrentada pelo Partido Comunista Francês depois dos reveses do comunismo soviético, bem como uma certa indiferença dos intelectuais ingleses em relação ao comunismo britânico. Elementos que definem uma cultura política própria a cada país; contextos diversos sob os quais os intelectuais aparecem, por conseguinte, de forma distinta à sociedade. Enquanto entre os franceses os intelectuais desfrutam de grande crédito, entre os ingleses não são vistos como figuras fundamentais. ${ }^{24}$

\footnotetext{
${ }^{22}$ A caracterização, muito particular, da política nacional francesa e a postura de seus intelectuais são questões que discutimos ao longo dos segundo e terceiro capítulos, pois são elementos centrais na interpretação de Furet sobre o século XX e a Revolução Francesa.

${ }^{23}$ Aron, R. O ópio dos intelectuais. Brasília, Editora UNB, 1980, p.203. Quanto aos intelectuais: “A arte dos intelectuais britânicos é reduzir a expressões técnicas conflitos muitas vezes ideológicos; a arte dos intelectuais americanos é transfigurar em disputas morais controvérsias que dizem respeito mais aos meios do que aos fins; a arte dos intelectuais franceses é ignorar e, muitas vezes, piorar os problemas próprios à nação, pela orgulhosa vontade de pensar para toda a humanidade”. p.209. Note-se que estas palavras são dirigidas, sobretudo, aos intelectuais franceses (de esquerda), daí o tom irônico e crítico.

${ }^{24}$ Aron coloca nos seguintes termos a questão: "A França exalta seus intelectuais, que a vomitam; os Estados Unidos não demonstram nenhuma indulgência para com seus intelectuais, que o exaltam...” p.196. "A GrãBretanha provavelmente é o país do Ocidente que tem tratado seus intelectuais de maneira mais razoável (...) Assim, evita-se o antiintelectualismo militante em que acaba, às vezes, o pragmatismo americano e a admiração que, na França, dirige-se indiferentemente aos romances e às opiniões políticas dos escritores, dando a estes últimos um sentimento excessivo de sua importância levando-os a julgamentos extremados e a artigos venenosos”. Id., ibid., p. 199. Também aqui Aron expõe uma avaliação parcial, mas não deixa de ser interessante, uma vez que oriunda de um intelectual imerso nessa problemática.
} 
A questão da relação entre o intelectual e a política conduz, portanto, à reflexão sobre a responsabilidade social do intelectual e à necessidade de identificação da cultura política de origem desse intelectual. Na verdade, são os limites da singularidade de cada ator histórico, pois, como bem observou Carlo Ginzburg a respeito de Menocchio: “da cultura do próprio tempo e da classe não se sai a não ser para entrar no delírio e na ausência de comunicação" ${ }^{25}$ Com as devidas reservas, notando sempre a contradição do intelectual quanto ao pertencimento a uma classe, essa constatação esclarece este preâmbulo sobre os intelectuais, visto que o trabalho do historiador (como de qualquer outro intelectual) está imerso em determinados pressupostos, dos quais selecionamos os mais influentes num possível condicionamento das visões de mundo de nossos dois historiadores.

O primeiro pressuposto é a cultura histórica ou historiográfica e as tradições de pensamento às quais está filiada. Existe um inevitável compromisso do historiador com essa primeira esfera de interlocução, nela residindo a responsabilidade do ofício e a exigência de verdade. O segundo pressuposto, já esboçado, é a cultura política e suas tradições de pensamento, uma esfera de interlocução que pode condicionar a atuação do historiador/intelectual na sociedade, mas só eventualmente podemos encontrá-la nas entrelinhas da obra historiográfica, dependendo muito da natureza desse trabalho. Dito isto, para investigar a política no pensamento historiográfico se fez forçoso entrecruzar essas diversas esferas para só então chegar à superfície presente do texto produzido pelo historiador e objeto deste estudo comparativo.

\section{História Intelectual e Historiografia}

De fato, as fontes documentais desta pesquisa possuem a particularidade de serem trabalhos historiográficos, de maneira que a análise documental foi realizada na confluência entre história intelectual e historiografia. História Intelectual porque objetivou compreender como a produção intelectual (do historiador) traduziu, por meio de um pensamento sistemático, algumas determinações exteriores. ${ }^{26}$ Historiografia porque versou sobre uma questão que diz respeito à configuração de seus próprios domínios, conteúdos, métodos e práticas; a obra de história foi, pois, julgada a partir de sua dupla condição de bibliografia e

\footnotetext{
${ }^{25}$ Ginzburg, C. O queijo e os vermes. São Paulo, Cia das Letras, 2002, p.27.

${ }^{26}$ Cf. Chartier, R. Intelectual (História). In: Burguière, A. (org.) Dicionário das Ciências Históricas. Rio de Janeiro, Imago Editora, 1993, p.446-452.
} 
documento. Não obstante, realizamos algumas adaptações teórico-metodológicas, na medida em que as fontes documentais e a trajetória de seus autores exigiram.

A primeira adaptação refere-se, evidentemente, à definição de História Intelectual. Existem diversas interpretações que distinguem ou equiparam História das Idéias, História Intelectual, História Cultural e História dos Intelectuais, gerando muita confusão quanto ao objeto. Optamos, então, por um dos termos e pela elaboração de uma definição pertinente para analisar as trajetórias e obras dos dois historiadores em questão. Com o termo História Intelectual foi possível abordar duas dimensões, a do texto e a do contexto, referindo-se tanto à obra intelectual quanto ao próprio intelectual. Para isso, combinamos elementos de duas grandes vertentes de interpretação, a francesa Histoire Intellectuelle (Sirinelli, Winock, Chartier, etc) e a dos anglo-saxões Intellectual History (Darnton, Skinner, Pocock, etc).

A abordagem dos autores anglo-saxões está situada, em geral, sobre as bases lingüísticas de uma obra de pensamento. Dois influentes autores dessa vertente são Quentin Skinner e John Pocock, sua intenção é interpretar o pensamento dos escritores políticos por uma aproximação com a filosofia da linguagem, partindo do resgate da linguagem para o das intenções dos autores. Seus indícios são sempre encontrados no texto, por meio dos “contextos lingüísticos”, os quais também levam à cultura política de uma época, visto que as linguagens empregadas pelos autores políticos “foram sancionadas como legítimas integrantes do universo do discurso público". ${ }^{27}$ Isso é possível pela investigação da forma de enunciação presente e disponível para uma série de autores, identificando se uma "linguagem” existia como recurso cultural para determinados atores da história. Essa investigação de um conjunto de textos é fundamental para Pocock, pois sustentar a existência dessa "linguagem” comum não seria o resultado de um mero olhar interpretativo.

Com o instrumental lingüístico proposto por Pocock foi possível avaliarmos as pressuposições subjacentes à linguagem dos historiadores, tornando explícito o que antes estava implícito. Contudo, descortinar insinuações e potencialidades de um discurso exige a prova do "contexto”, ou seja, da comparação com outras obras contemporâneas. O limite seria, portanto, o paralelo entre Hobsbawm e Furet. Em outros termos, a abordagem de Pocock só pode ser levada às últimas conseqüências quando se parte de uma perspectiva horizontal ou sincrônica para a identificação de uma determinada “linguagem”. Nossa

\footnotetext{
${ }^{27}$ Pocock, J. G. Linguagens do ideário político. São Paulo, Edusp, 2003, p.31.
} 
pesquisa esteve concentrada, entrementes, na dimensão vertical ou diacrônica das fontes documentais, método condizente com sua natureza historiográfica. ${ }^{28}$

De resto, a noção de “contexto lingüístico” foi muito frutífera para a análise, por exemplo, da historiografia da Revolução Francesa, visto que para examinar seu revisionismo identificamos um conjunto de regras que dominou a tradição de pensamento sobre essa revolução, tanto na dimensão diacrônica quanto sincrônica. A referência ao debate com toda uma historiografia contemporânea foi fundamental. Neste sentido, foi possível abordarmos os participantes de um debate historiográfico/político como atores históricos atuando em uma diversidade de “contextos lingüísticos” (modos de discurso estáveis, um jogo definido por uma estrutura de regras), ${ }^{29}$ ou seja, a história resgatada de seu debate. ${ }^{30}$

Em suma, parte-se da decomposição do texto à sua recombinação como articulação da consciência do autor e como um ato de comunicação em um continuum discursivo que envolveu outros autores. ${ }^{31}$ Um processo analítico que conduziu ao esboço das culturas política e histórica nas quais atuaram os dois historiadores, traços reforçados pela interpretação à francesa da História Intelectual. Entre os historiadores franceses mais comprometidos com a elaboração de uma metodologia adequada para o estudo dos intelectuais, destaca-se JeanFrançois Sirinelli, cujo programa visa ultrapassar a "história do discurso”, procurando situar a história dos intelectuais no cruzamento das histórias política, social e cultural. Um ponto de vista mais amplo e até ambicioso, por intercalar ideologias, cultura política e mentalidades coletivas, transformando a "história dos intelectuais em um observatório de primeira ordem" para uma história global. ${ }^{32}$

Não se trata de abordarmos o programa inteiro de Sirinelli, apenas alguns conceitos foram de grande utilidade ao longo deste trabalho, suprindo as lacunas referentes às culturas

\footnotetext{
28 "O historiador procura localizar e interpretar temporalmente o artefato num campo em que se intersectam duas linhas. Uma linha é vertical, ou diacrônica, pela qual ele estabelece a relação de um texto ou de um sistema de pensamento com as manifestações anteriores no mesmo ramo de atividade cultural (pintura, política, etc). A outra é horizontal, ou sincrônica; através dela, determina a relação do conteúdo do objeto intelectual com o que vai surgindo ao mesmo tempo noutros ramos ou aspectos de uma cultura”. Schorske, C. Citado por Helenice Rodrigues da Silva In: LOPES, M. A. (org.) Grandes nomes da história intelectual. São Paulo, Contexto, 2003, p.15. Convém esclarecer que a dimensão sincrônica de Carl Schorske se refere, mais precisamente, à produções culturais contemporâneas e de outros ramos que não o do autor estudado, mas a diversidade de textos historiográficos contemporâneos mereceria este foco sincrônico e é nesse sentido que a aproximação com a idéia de "contextos lingüísticos" é possível.

${ }^{29}$ De acordo com Pocock o domínio dessas linguagens ou regras do jogo, "nos possibilitará considerar o modo pelo qual os jogadores exploraram as regras uns contra os outros e, no devido tempo, como atuaram sobre as regras com o resultado de alterá-las”. Cf. Pocock, J. Op. cit., p.31.

${ }^{30}$ Cf. Id., ibid., p.23.

${ }^{31}$ Cf. Id., ibid., p.54.

${ }^{32}$ Cf. Sirinelli, J-F. Os Intelectuais. In. Rémond, R. Op. cit., p.262.
} 
políticas e trajetórias dos historiadores. As noções de itinerário, geração e sociabilidade permitiram o avanço para fora do texto, ou seja, a inscrição histórica dos atores. A observação e o cotejo de itinerários intelectuais foi o primeiro passo, mas não livre de problemas, uma vez que a reconstituição e a interpretação dos itinerários de Eric Hobsbawm e de François Furet exigiram perspectivas diferentes. De acordo com Sirinelli essa "extrema diversidade das situações individuais impede que se chegue a explicações globalizantes”. ${ }^{33}$ Duas situações, entretanto, foram localizadas por este historiador: "a imagem de fidelidade de um intelectual ao engajamento de toda uma vida, desde as primeiras leituras infantis até os ensaios outonais"; e os caminhos que seguem linhas fragmentadas. ${ }^{34}$

A primeira situação aponta, de forma imprecisa, para a trajetória de Eric Hobsbawm, cuja reconstituição foi possível mediante idéias e racionalizações apresentadas pelo próprio historiador, que reivindicou conscientemente a fidelidade a determinadas causas e projetos. Seu percurso intelectual, senão mesmo pessoal, não sofreu grandes reveses, e mesmo com a crítica dessas racionalizações percebemos elementos constantes, cujo desconhecimento levarnos-ia a prescindir de importantes indícios de intenção, basilares para a interpretação de sua obra. Trata-se de uma trajetória muito particular e, embora contemporâneo de Furet, Hobsbawm não partilhou da mesma cultura política e nem dos anseios da mesma geração, por conseguinte, seu trabalho desfrutou de diferentes pressupostos, fato que tentamos explorar no decorrer dos capítulos seguintes.

François Furet, pelo contrário, apresentou uma trajetória intelectual labiríntica e de difícil apreensão, decerto pertenceu a uma geração de intelectuais exaustivamente estudada, que seguiu "linhas fragmentadas", mas sua personalidade ímpar resultou em respostas inusitadas aos contextos que vivenciava e à historiografia, fato que o colocou em lugar de destaque entre os historiadores franceses. Pertencer a uma geração é um fenômeno natural e também cultural, pode ser resultado de uma reconstrução do historiador que classifica e rotula, como pode ser uma auto-representação. ${ }^{35}$ Furet sempre se reivindicou filho de uma determinada geração que criou lugares de sociabilidade duradouros. Sua geração é aquela, citada por Sirinelli, “nascida em torno de 1925 e seduzida 20 anos depois pelo comunismo”, compondo o grande estrato dos “ex” (comunistas) após 1956. ${ }^{36}$

\footnotetext{
${ }^{33}$ Id., ibid., p.247.

${ }^{34}$ Cf. Id., ibidem.

${ }^{35}$ Cf. Sirinelli, J-F. A Geração. In: Ferreira, M. M e Amado, J. (orgs.) Usos \& abusos da história oral. Rio de Janeiro, Editora FGV, 2000, p.133.

${ }^{36}$ Cf. Sirinelli, J-F. Os Intelectuais. In: Rémond, R. Op. cit., p.246.
} 
Essa geração foi, provavelmente, a responsável pelo desenvolvimento crescente do estudo sobre os intelectuais, chamando atenção por sua reação crítica à desilusão com o comunismo. Em conseqüência disso, dispomos hoje de uma abundante quantidade de bibliografia e documentação sobre o tema (sobretudo na França). ${ }^{37}$ Pode-se investigar não só a obra ainda em andamento de um sem número de intelectuais como também os infinitos trabalhos sobre esses intelectuais e sobre as sua obras. Um obstáculo intransponível se buscarmos o levantamento exaustivo desses estudos, porquanto a seleção bibliográfica foi inevitável para não perdermos de vista nosso objeto.

Quanto aos lugares e redes de sociabilidade, tanto Hobsbawm quanto Furet freqüentaram os meios universitários, os grupos e instituições de pesquisa e a imprensa. São nestes lugares com o diz-que-diz que, segundo Sirinelli, "se interpenetram o afetivo e o ideológico". ${ }^{38}$ As solidariedades de idade, classe e profissão tecem redes de transmissão cultural, e são nestes meios que procuramos os interlocutores dos autores estudados, pois como já disse Jacques Julliard "as idéias não passeiam nuas pela rua, elas são levadas por homens que pertencem eles próprios a conjuntos sociais”. ${ }^{39}$ Foi justamente a identificação dessas sociabilidades, dessas redes de discurso e práticas, por meio da bibliografia, que nos permitiu completar o esboço das culturas políticas e histórica sob as quais atuaram os dois historiadores.

Outra questão acompanhou este paralelo entre Hobsbawm e Furet, é a proximidade temporal do objeto, pode-se dizer que lidamos com a chamada História do Tempo Presente. Note-se que ambos os autores escreveram sobre seu próprio tempo, aliás, em seus trabalhos sobre o século XX chegaram ao que podemos denominar História Imediata, quase na fronteira com o jornalismo. No entanto, diferentemente deles, já não temos a oportunidade de presenciar a força das ideologias que permearam a trajetória dos intelectuais durante a maior parte do século XX, e, mesmo revisitando essas ideologias, os novos contextos provocam um inevitável distanciamento das paixões então mobilizadas. Ainda assim, devemos evitar o excesso de racionalizações, pois um dos historiadores (Hobsbawm) continua a produzir e em

\footnotetext{
${ }^{37}$ Isso pode ser explicado pelo impacto das desilusões ideológicas durante o século XX, muito mais patentes entre os franceses. Ao comparamos com os intelectuais ingleses o distanciamento entre as culturas políticas se faz evidente. Talvez seja impensável um intelectual como Hobsbawm, ainda comunista, entre os franceses, para os quais se um dia foi impensável ser de esquerda e não ser comunista, hoje parece impensável continuar a sê-lo.

${ }^{38}$ Sirinelli, J-F. Os Intelectuais. In: Rémond, R. Op. cit., p.252.

${ }^{39}$ Julliard, J. Citado por Sirinelli, J-F. In. Id., ibid., p.258.
} 
determinados momentos suas novas reflexões foram aqui recolhidas para esclarecer algumas questões de seu “sistema de pensamento”, uma proximidade que exigiu atenção. ${ }^{40}$

Com isso, contemplamos a prática social dos historiadores e a evolução de seu pensamento histórico, mas o tema da política na historiografia só pôde ser efetivamente abordado por meio da própria historiografia. Após refletir sobre as condições que determinaram a produção e a natureza das obras históricas, as colocamos em confronto, buscando as diferenças, semelhanças e nuances entre os discursos historiográficos. O tratamento documental da obra historiográfica adquiriu, então, a dimensão política inerente à interpretação historiográfica, visto que se enfrenta questões referentes aos seus próprios domínios e à ação do historiador. Procuramos abordar a gênese e a significação histórica das obras transpondo a fronteira entre as idéias explícitas e os sistemas de pensamento por meio da crítica de interpretação. Com sistemas de pensamento não buscamos teorias e coerência de interpretação, mas a sistematização comum a um trabalho historiográfico, ou mesmo alguns elementos permanentes na linguagem ou interpretação do historiador.

Ademais, nesta confluência entre história intelectual e historiografia lidamos com uma vasta gama de temas e acontecimentos da história mundial recente, cuja percepção e condições de percepção constituem o nosso objeto primeiro. Neste caso, os atos políticos adquirem maior destaque, pois é o inesperado que, não raro, motivou as reações intelectuais. Como bem discerniu René Rémond, “daí os acontecimentos políticos serem fundadores de mentalidades: o acontecimento solda uma geração, e sua lembrança continuará sendo até o último suspiro uma referência carregada de afetividade, positiva ou negativa, até que, com o desaparecimento desta, ele mergulha na inconsciência da memória coletiva, onde continuará, no entanto, a exercer alguma influência insuspeitada”. ${ }^{41}$ Assim, mais uma vez, justifica-se esta comparação, os fatos e situações abordados por Hobsbawm são praticamente os mesmos de Furet, são as situações internacionais que marcaram suas gerações, problemas nacionais paralelos ou então temas que a historiografia trouxe à voga, tocando a ambos em momentos próximos.

Diante disso, a análise política também foi um de nossos instrumentos de trabalho, em especial a sua orientação semântica, pois, como destacou Robert Dahl, o esclarecimento do

\footnotetext{
${ }^{40}$ Para René Rémond "a história do tempo presente é um bom remédio contra a racionalização a posteriori, contra as ilusões de ótica que a distância e o afastamento podem gerar”. In: Ferreira, M. M e Amado, J. (orgs.) Op. cit., p.209.

${ }^{41}$ Rémond, R. Do Político. In. Por uma história política, op. cit., p.449.
} 
sentido dos termos que usamos é um elemento importante, já que muitos desses termos não possuem uma definição aceita ordinariamente. ${ }^{42} \mathrm{O}$ uso ou aplicação de conceitos e outros termos, nos documentos cotejados, mereceu atenção redobrada, pois as divergências podiam esconder problemas semânticos de fundo, como no caso do conceito de totalitarismo. A análise política permitiu, também, a incursão aos principais temas da política contemporânea, substancialmente presentes nas fontes documentais. Acreditamos, com isso, ter explicitado a importância desses dois pensadores para a historiografia e para a compreensão dos dilemas políticos que permearam a existência dos homens e mulheres do século XX.

Para levar a efeito este projeto, além das fontes documentais consultamos uma rica bibliografia e realizamos um levantamento bibliográfico das obras de Hobsbawm e de Furet. Intentamos recolher aqui o conjunto de seus trabalhos, mas esse levantamento pode revelar lacunas quanto aos artigos de periódicos e de obras coletivas, visto que tais publicações, além de numerosas, foram realizadas em diversos países e numa grande variedade de revistas especializadas. Por enquanto, o levantamento dos livros parece ter chegado à exaustão, excluindo-se as possíveis coletâneas não organizadas pelos autores. Por fim, devemos pontuar que todos os procedimentos apresentados acima não dariam conta da erudição crítica, possível mediante o que consideramos o foco temático e metodológico deste estudo: o exercício sistemático de comparação e confrontação. ${ }^{43}$

\footnotetext{
${ }^{42}$ Cf. Dahl, R. A. Análise política moderna. Brasília, Editora da Universidade de Brasília, 1981, p.16.

${ }^{43}$ Cf. Boutier, J. e Julia, D. (org.) Passados recompostos: campos e canteiros da história. Rio de Janeiro, UFRJ, 1998, p.37.
} 
CONSIDERAÇÕES FINAIS 
Ao confrontar as trajetórias intelectuais de Eric Hobsbawm e de François Furet procuramos evidenciar, ao longo deste estudo, as relações fundamentais entre o pensamento histórico e o pensamento político, não só na historiografia, mas também na história tout court e, sobretudo, no percurso desses dois indivíduos que viveram, pensaram e transformaram, ainda que em pequeníssima escala, o século XX. Dessa maneira, nestas considerações finais pretendemos apenas pontuar a questão do nosso pressuposto temático, ou seja, as relações entre história, política e revolução presente nos trabalhos e trajetórias de nossos dois historiadores. Com esse pressuposto pretendíamos abarcar o conjunto de suas reflexões naquilo que possuíam de comparável, mas suas trajetórias envolventes puderam nos levar muito além da historiografia, e este paralelo acabou revelando a importância desses dois pensadores também para a compreensão dos dilemas políticos que permearam a existência da maioria dos homens e mulheres do século XX.

Dessa maneira, acreditamos que nosso pressuposto temático tenha ajudado a elucidar o conjunto da obra de Hobsbawm e de Furet paralelamente. Revelando que, apesar dos contrastes, as visões de história, política e revolução de ambos possuíam as suas devidas fundamentações, não cabendo julgamentos de valor que tendem para o âmbito da polêmica ideológica. Destacamos este aspecto por tê-lo identificado como uma constante nas avaliações historiográficas, uma vez que nosso estudo enfrentou a presença dessa questão a partir, justamente, da relação entre história e política. O tema mesmo de reflexão de Hobsbawm e de Furet partia dessa relação no mundo contemporâneo, desde seus primórdios sob o pensamento revolucionário. Ora, como escapar das guerras ideológicas tão características do século XX, ainda mais ao confrontar representantes de duas tendências opostas? Por isso procuramos não ignorar algumas dessas polêmicas, mas recolhê-las como parte efetiva da realidade que estivemos abordando. Ademais, ao expor as trajetórias de vida de cada um dos autores, tentamos mostrar, não justificar, a formação e reformulação de suas posições intelectuais. Afinal, sob este aspecto, seja pelo socialismo, seja pela democracia liberal, cada um desejou, à sua maneira, um mundo melhor. 


\section{BIBLIOGRAFIA}


A lista que segue, além de relacionar os documentos e trabalhos consultados, também oferece levantamentos bibliográficos do conjunto da obra de Eric Hobsbawm e François Furet. Este arrolamento decerto não é exaustivo, mas procuramos identificar o máximo possível de trabalhos realizados pelos dois historiadores. No entanto, é importante esclarecer que, em relação aos artigos, listamos, sobretudo, aqueles ainda não publicados em coletâneas, pois já podem ser localizados a partir da lista de livros.

\section{I - Fontes}

HOBSBAWM, E. The Age of Revolution. Europe 1789-1848. Londres, Weidenfeld \& Nicolson Ltd, 1962 [Ed. Brasileira: A Era das Revoluções: Europa 1789-1848. Rio de Janeiro, Paz e Terra, 1977].

. Echoes of the Marseillaise: Two centuries look Back on the French Revolution. Rutgers, 1990 [Ed. Brasileira. Ecos da Marselhesa: Dois Séculos Revêem a Revolução Francesa. São Paulo, Cia das Letras, 1996].

Age of Extremes. The Short Twentieth Century, 1914-1991, Londres, Michael Joseph, 1994. [Ed. Brasileira: Era dos Extremos: O breve século XX: 19141991. São Paulo, Cia das Letras, 1995].

On History. New Press, 1997. [Ed. Brasileira: Sobre História. São Paulo, Companhia das Letras, 1998].

FURET, F. RICHET, D. La Revolution Française. Paris, Hachette, 2vol., 1965/66. (Nova Edição: Paris, Fayard, 1973).

FURET, F. Penser la Révolution Française. Paris, Gallimard, 1978. [Ed. Brasileira: Pensando a Revolução Francesa. Rio de Janeiro, Paz e Terra, 1989].

L'Atelier de l'Histoire. Paris, Flammarion, 1982. [Ed. Portuguesa: A Oficina da História. Lisboa, Gradiva, 1989].

. Le passé d'une Illusion: Essai sur l'Idée Communiste au XXe Siècle. Paris, Laffont-Calmann-Lévy, 1995 [Ed. Brasileira: O Passado de uma Ilusão: Ensaios sobre a Idéia Comunista no Século XX. Siciliano, São Paulo, 1995]. 


\section{II - Levantamento Bibliográfico - Eric Hobsbawm}

\section{A) Livros}

HOBSBAWM, E. (ed.) Labour's Turning Point, 1880-1900: Extrats From Contemporary Sources. Londres: Lawrence \& Wishart, 1948.

Rebeldes Primitivos: Estudos sobre Formas Arcaicas de Movimentos

Sociais nos Séculos XIX e XX. (1959). Rio de Janeiro, Zahar, 1978.

. História Social do Jazz. (1959) Rio de Janeiro, Paz e Terra, 1990.

. Trabalhadores: Estudos sobre a História do Operariado. (1964) Rio de

Janeiro, Paz e Terra, 1981.

. Introdução. In MARX, K. Formações Econômicas Pré-capitalistas (1964).

Rio de Janeiro, Paz e Terra, 1991.

Da Revolução Industrial Inglesa ao Imperialismo.(1968) Rio de Janeiro,

Forense Universitária, 1979.

. Bandidos. (1969) Rio de Janeiro, Forense, 1975.

e RUDÉ, G. Capitão Swing: a Expansão Capitalista e as Revoltas Rurais na

Inglaterra do inicio do Século XIX (1969). Rio de Janeiro, Francisco Alves, 1982.

. Lenin y la “aristocracia obrera” (1971) In. LENIN. Imperialismo y

movimiento obrero: las raíces del oportunismo. Barcelona, Editorial Anagrama, 1976. Revolucionários: Ensaios Contemporâneos.(1973) Rio de Janeiro, Paz e

Terra, 1982.

. A Era do Capital: 1848-1875. (1974) Rio de Janeiro, Paz e Terra, 1982. . (org.) A História do Marxismo. (1978-82) Vários Vols. Rio de Janeiro, Paz e

Terra, 1987.

e RANGER, T. Invenção das Tradições.(1983) Rio de Janeiro, Paz e Terra, 1997.

Mundos do Trabalho: Novos estudos sobre História Operária. (1984) Rio de Janeiro, Paz e Terra, 1987.

. A Era dos Impérios:1875-1914.(1987) Rio de Janeiro, Paz e Terra, 1988 . Estratégias para uma esquerda racional.(1989) Rio de Janeiro, Paz e Terra, 1991. 
HOBSBAWM, E. Nações e Nacionalismo desde 1780: Programa, Mito e Realidade. (1990) Rio de Janeiro, Paz e Terra, 1990. .Pessoas Extraordinárias. (1998) São Paulo, Companhia das Letras, 1999. . O Novo Século.(1999) São Paulo, Cia das Letras, 2000. . Tempos Interessantes: Uma Vida no Século XX. (2002) São Paulo, Companhia das Letras, 2002. SPIRE, A L'Optimisme de la Volonté: d'un Siécle à l'Autre. Paris, Le Bord De L'eau Editions, 2003.

\section{B) Artigos}

HOBSBAWM, E. The General Crisis of the european economy in the $17^{\text {th }}$ Century: I. Past and Present, n 5, may p 33-56, 1954 The Crisis of the $17^{\text {th }}$ Century: II. Past and Present, n 6, november, p 44-65, 1954 The Seventeenth Century in the developement of Capitalism. Science and Society, n 24, p 97-112, 1960.

Parliamentary Cretinism? (book review) New Left Review, NovemberDecember pp. 64-6, 1961.

Hyndman and the SDF (book review), New Left Review, July-August pp. 69-72, 1961

. En Angleterre Révolution industrielle et vie matérielle des classes populaires. Annales ESC, a. 17, p. 1046, 1962. . Mysteries of Economic Growth New York Review of Books June 25, 1964 . Koestler's England New York Review of Books ,April 2, 1964. .You Can't Go Home Again. New York Review of Books ,September 30, 1965 . The Rioting Crowd. New York Review of Books, April 22, 1965. . A Christian Materialist New York Review of Books ,March 11, 1965. Alive and Kicking, New York Review of Books, October 20, 1966. 1848 and All That New York Review of Books , June 1, 1967. 
e STONE, L. The survival of the nobility during the French Revolution:

Notes Past and Present, n 39, Apr. p.173, 1968.

HOBSBAWM, E. Les soulèvements de la campagne anglaise, 1780-1850. Annales ESC, a. 23, p. 9, 1968.

. How to Plot Your Takeover. New York Review of Books, August 21, 1969

Birthday Party, New York Review of Books , May 22, 1969.

Is Science Evil?, New York Review of Books, November 19, 1970.

. What's New in Peru New York Review of Books, May 21, 1970.

. A Special Supplement: Chile: Year One New York Review of Books,

September 23, 1971.

. Latin America as US Empire Cracks March. New York Review of Books, 25, 1971.

Peru: The Peculiar "Revolution", New York Review of Books, December 16,

1971

. E. Passionate Witness. New York Review of Books, February 22, 1973

. The Great Gramsci. New York Review of Books, April 4, 1974

. Peasant Land Occupation. Past and Present, n 62, Feb. p. 120, 1974

. La diffusione del marxismo (1890-1905), Studi Storici, Roma, a. XV, p.

241,1974

. Dictatorship with Charm New York Review of Books ,October 2, 1975

. Vulnerable Japan New York Review of Books, July 17, 1975

Some Reflections on 'The Break-up of Britain'. New Left Review,

September-October pp. 3-23, 1977

. Comments. Review, a Journal of the Fernand Braudel Center, vol 1,

number 3-4, pp 157-162, 1978

. Capitalisme et agriculture: les réformateurs écossais au XVIIIe siècle.

Annales ESC, a. 33, p.580, 1978

. La Culture Ouvriere en Angleterre.L'Histoire, nº17, Paris, nov 1979

. Uomo e donna nell'iconografia socialista. Studi Storici, Roma, a. 20, p. 705,

1979

e SCOTT, J, W. Political Shoemakers. Past and Present, n. 89, Nov. p.86,

1980 
Pact with the Devil. New York Review of Books, December 18, 1980

. Publick Benefits and Private Vices. New York Review of Books, April 3,

1980

HOBSBAWM, E. Un livre étranger? Barrington Moore Jr. Injustice. Le Débat, n 1 , mai-, p. 128, 1980

. The Lowest Depths New York Review of Books, April 15, 1982 Retour au récit ? Réponse à Lawrence Stone Le Débat ,n² 23, janv.- p.

153,1983

e HILL, C. HILTON, R. Origins and Early Years. Past and Present, n. 100,

Aug. p.3, 1983

.On the Watch, New York Review of Books, December 8, 1983

.Marx e la conoscenza storica. Studi Storici, Roma, p.335, 1983

. Artisan or Labour Aristocrat? The Economic History Review, London, a.

37, p. 355, 1984

Revolution in the theory of Karl Marx. In. CHAVANCE, B. (ed.) Marx en

Perspective. Paris, Éditions de L'Ècole des Hautes Études em Sciences Sociales, 1985. . Robin Hood, New York Review of Books, February 14, 1985

. Revolution. PORTER, R. TEICH, M. Revolution in History. Cambridge

University Press, 1986

. Murderous Colômbia New York Review of Books November 20, 1986

. 'Playing for Ourselves' New York Review of Books, January 16, 1986

. The Jazz Comeback New York Review of Books February 12, 1987

. The Caruso of Jazz. New York Review of Books, May 12, 1988

. Some Like It Hot. New York Review of Books April 13, 1989

.The Making of a “Bourgeois Revolution”. Social Research, vol.56,

spring, pp. 5-31,1989

. Escaped Slaves of the Forest. New York Review of Books, December 6,

1990

. Uma Entrevista com Eric J. Hobsbawm (entrevista). Estudos Históricos,

Rio de Janeiro, vol.3, n.6, pp 264-273,1990

. The Crisis of Today's Ideologies New Left Review, March-April pp. 55-64,

1992 
. The New Threat to History, New York Review of Books, December 16,

1993

. Histoire et Illusion. Le Débat, nº 89, mars-avril, p. 128, 1996

HOBSBAWM, E. Identity Politics and the Left. New Left Review, May-June, p.38-47, 1996 . L'Âge des Extrêmes. Commentaires. Le Débat, n 93, janv.-fév, p.85, 1997.

L’Age des extrêmes » échappe à ses censeurs. Le Monde Diplomatique, septembre, p. 28-29, 1999

Francis Haskell. Past and Present, August, p. 3-5, 2000.

. A Life in History Past and Present, n 177, p 3-16, 2002

. Le Pari de la Raison - Manifeste pour L'Histoire. Le Monde Diplomatique, nº09, p.20-21, decembre, 2004

. A sombra que nos protege. Folha de Sao Paulo, Caderno Mais!, 6/11/2005

\section{III - Levantamento Bibliográfico - François Furet}

\section{A) Livros}

FURET, F. e DAUMARD, A Structures et Relations Sociales a Paris au Milieu du XVIIIe Siècle. Paris, A. Colin, 1961.

e BOUVIER, GILLET, M. Le Mouvement du Profit en France au XIXe Siècle

Paris, Mouton, 1965

(et al.). Livre e Societe dans la France du XVIIIe Siecle. Paris, Mouton, 1965.

e BERGERON, L KOSELLECK, R La Época de las Revoluciones Europeas, 1780-1848 (1969). Madri, Siglo XXI, 1989.

Discours / Mirabeau; édition établie, présentée et annotée par François Furet.

Paris, Gallimard, 1973.

e OZOUF, J. Lire et écrire: l'alphabétisation des Français de Calvin à Jules

Ferry. 2v. Paris, Editions de Minuit, 1977.

. Ensaios sobre a Revolução Francesa. Lisboa, A Regra do Jogo, 1978.

e LINIERS, A. RAYNAUD, P. Terrorisme et Démocratie. Paris, Fayard, 1985. 
FURET, F. (presenté par) Jules Ferry: fondateur de la République (École des Hautes Études em Sciences Sociales - Colloque (1982: Paris). Paris, Editions de l'EHESS, 1985. . La Gauche et la Révolution Française au Milieu du XIXe Siècle: Edgar Quinet et la Question du Jacobinisme, 1865-1870. Paris, Hachette, 1986 e CALVIÉ L., Marx et la Révolution Française. Paris, Flammarion, 1986 Marx e a Revolução Francesa. Rio de Janeiro, Jorge Zahar Editor, 1989 e GIESEY, R. EBNOTHER, D. Le Roi ne meurt jamais: les obsèques royales dans la France de la Renaissance. Paris, Flammarion, 1987 e JULLIARD, J. ROSANVALLON, P. La République du Centre : la Fin de l'Exception Française. Paris, Calman Levy, 1988. . La Révolution 1770-1880. Paris, Hachette, 2v, 1988 e OZOUF, M. Dicionário Crítico da Revolução Francesa (1988). Rio de Janeiro, Nova Fronteira, 1989 e HALÉVI, R (org) Orateurs de la Révolution Française. in Les Constituants tome I,. Paris, Gallimard, La Pléiade, 1989 .(org.) L'Héritage de la Révolution Française. Paris, Hachette, 1989 (et al.). The French Revolution and the Creation of Modern Political Culture. (1989) 4v. Oxford, Pergamon Press, 1994 e OZOUF, M La Gironde et les Girondins. Paris, Payot, 1991 e OZOUF, M. (org.) Le Siècle de l'Avènement Républicain. Paris, Gallimard, 1992.

e DAHRENDORF, R GEREMEK, B. La Democrazia in Europe Roma, Laterza, 1992.

. (et al.) O Homem Romântico. (1995) Lisboa, Presença, 1999 . et HALEVI R., La Monarchie Républicaine, la Constitution de 1791 in

"Histoire des constitutions de France". Paris, Fayard, 1996 . Entretiens du Patrimoine 1996. Paris, Fayard, 1997 e NOLTE, E. Fascismo e Comunismo (1998). Lisboa, Gradiva, 1999 . Un Itineraire Intellectuel. Paris, Calmann-lévy, 1999 . A Revolução em Debate.(1999) Bauru-SP, EDUSC, 2001 


\section{B) Artigos}

FURET, F Structures sociales parisiennes au XVIIIe siècle: l'apport d'une série " fiscale". Annales ESC, a. 16, p. 939, 1961

. Pour une définition des classes inférieures à l'époque moderne. Annales ESC,

a. 18 , p. 459,1963

BERGERON, L. e MAZAURIC, C. Les Sans-culottes et la Révolution

française. Annales ESC ,a. 18, p. 1098, 1963

. Renouveau de l'étude des Lumières. Annales ESC, a. 19, p.885, 1964

. Tocqueville est-il un historien de la Révolution française ? Annales ESC, a. 25,

p. 434, 1970

. SACHS, W. La croissance de l'alphabétisation en France

(XVIII e-XIXe siècle. Annales ESC, a. 29, p.714, 1974

. Ancien Régime et Révolution - Réinterprétations: Présentation. Annales

ESC, a. 29, p.3, 1974

e OZOUF, J. Trois siècles de métissage culturel, Annales ESC, a 32, p. 488,

1977

. Comment Kissinger a conquis Nixon Le Nouvel Observateur, no 781, 29 oct. ,

p. 60-61 1979.

FURET, F e GUERIN, D. Procès à Robert Hossein Le Nouvel Observateur, no 787, 10 déc. , p. 106-108 1979.

. Le XIXe Siècle et l'Intelligence du Politique. Le Débat, n ${ }^{\circ}$, mai- p. 12, 1

. (et. al.) A quoi pensent-ils Le Nouvel Observateur, no 810, 19 mai , p. 52-58.

1980

. En Marge des Annales. Histoire et Sciences Sociales. Le Débat, n 17, déc.- p.

112, 1981

- (et al.) Plaidoyer pour une vieille dame indigne Le Nouvel Observateur, no

851, 2 mars, p. 42-50. 1981

. Les coulisses du délire Le Nouvel Observateur, no 888, 14 nov. , p. 50-51.1981

. Allons enfants...Le Nouvel observateur, no 945, 18 déc. , p. 52-54. 1982

.En attendant Lénine Le Nouvel Observateur, no 908, 3 avril, p. 59. 1982

.Les énigmes de sir Karl Le Nouvel Observateur, no 904, 6 mars, p. 54.1982 
.Une Certaine Idée de la France. (Entretien) Le Débat, n² 26, sept. p. 5, 1983

FURET, F. Faut-il Celebrer le Bicentenaire de la Révolution Française. (Entretien).

L'Histoire, nº52, Paris, janvier, 1983.

. Camarade artisan Le Nouvel observateur, no 989, 21 oct. , p. 49-50. 1983

. Le condamné du Cherche-Midi» Le Nouvel observateur, no 994, 25 nov, p. 56-

57.1983

. Notre oncle d'Amérique Le Nouvel observateur, no 977, 29 juill. , p. 54-

55.1983

. Chicago: le Noir joue et gagne Le Nouvel observateur, no 963, 22 avril, pp. 36-

37. 1983

. Une certaine idée de la France. Entretien avec François Furet /Barre Raymond, Le Débat, n²6, sept, p. 5.1983

. Une Polémique Thermidorienne sur la Terreur, Passé Présent, n 2,1983

. Dieu à la droite de Reagan» Le Nouvel observateur, no 1040, 12 oct. , p. 30-31.

1984

. La fin d'une idylle Le Nouvel observateur, no 1015, 20 avril, p. 551984.

. La chanson de Ronald Le Nouvel observateur, no 1043, 2 nov. , p. 31.1984

. Le Jeune Marx et la Révolution Française. Le Débat, nº 28, janv.- p. 30, 1984

. Faut-il Avoir Peur de 1989 ? Réponse à Maurice Agulhon. Le Débat, nº 30,

mai-, p. 38, 1984

e SITBON, G Plus Reagan que Reagan: Super-Reagan Le Nouvel observateur, no 1044, 9 nov. , p. 20-23. 1984

. Faut-il avoir peur de 1989? Réponse à Maurice Agulhon Le Débat, n 30, mai-, p. 381984

Naissance d'un paradigme: Tocqueville et le voyage en Amérique (1825-1831). Annales ESC, a. 39, p225, 1984

. Vous avez dit libéral Le Nouvel observateur, no 1069, 3 mai, p. 62-63. 1985

. The Passions of Tocqueville New York Review of Books, June 27, 1985

.La découverte de l'Amérique [par Alexis de Tocqueville] Magazine littéraire, no 236, déc. , p. 35-40.1986

. Burke ou la fin d'une seule histoire de l'Europe Le Débat, n 39, mars-mai, p.

561986 
Une Méthode en Politique. (Entretien) Le Débat, n 38, janv.-mars, p. 4, 1986

FURET, F. Le premier dialogue de sourds de Raymond Aron Le Nouvel observateur, no

1146, 24 oct. , p. 54.1986

. L'Université est-elle réformable ? Le Débat, n 45, mai-sept. , p. 61987

. De la cour au ghetto Le Nouvel observateur, no 1191, 4 sept. , p. 62-64. 1987

. L'existentielle anarchie Le Nouvel observateur, no 1166, 13 mars, p. 64. 1987

. L'Aventure des Idées. 1956. La Gauche Française entre dans l'Après-Guerre. Le

Débat, $\mathrm{n}^{\circ}$ 50, mai-août, p. 20, 1988

.O Historiador e a História (Entrevista). Estudos Históricos, Rio de Janeiro,n 1, p. 143-161, 1988.

.Droite, Gauche, Centre. Sur Quelques Objections. Le Débat, n 52, nov.-déc. , p. 11,1988

. Le refus de la Révolution : chouans, déserteurs, insoumis ; la réaction

insurrectionnelle Le Nouvel observateur, no 1236, 15 juill, p. 58-59. 1988.

. Les hommes de Louis XVI jouent le prologue de la Révolution Historia, no 504, déc. , p. 42-53. 1988

. L'Église, la Révolution et les droits de l'homme. Entretien avec François Furet/

Lustiger, Cardinal Jean-Marie, Le Débat, n 55, mai-août , p. 31989

. Vie de Chine Le Nouvel Observateur, no 1305, 9 nov. , p. 771989.

. La Tragédie Allemande, l'Europe et l'Histoire. L'Histoire, nº118, Paris, janvier

1989

. 1789: si c'était à refaire ... Le Nouvel Observateur, no 1261, 5 janv. p. 42-44,

1989

. Au club des Jacobins Le Nouvel Observateur, no 1278, 4 mai, p. 77.1989

e HALEVI, R. L’Année 1789. Annales ESC, Paris, janvier-février 1989

. Ancien Régime et Révolution [française]: l'enseignement de l'histoire Historia,

no 508, avril , p. 7-15. 1989

. Robespierre est-il coupable [de la Terreur]? L'Express international, no 1983,

14 juill. , p. 38-51 1989.

. 1789: une idée qui a changé le monde». / Entretien avec François Furet. Le

Courrier de l'Unesco, 42e année, juin , p. 10-57.1989 
. La Commune, dernier soubresaut de la Révolution [française] Historia, no 514, oct. , p. 28-40. 1989

. De l'indépendance des universités [en France]L'Express international, no 1960, 3 févr. , p. 20. 1989

FURET, F. L'Énigme de la Désagrégation Communiste. Le Débat, n 62, nov.-déc. , p. 166 1990

Les résistibles mystères de l'Ancien Régime Le Nouvel Observateur, no 1355, 25 oct. , p. 74-75 1990.

. Les énigmes de l'Europe Le Nouvel Observateur, no 1335, 7 juin, p. 70.1990

. A commentary. French Historical Studies, vol. 16, nº4, fall pp 792-802, 1990.

. Les feuilles mortes de l'utopie Le Nouvel Observateur, no 1329, 26 avril, p. 36-

38. 1990

. [Compte rendu de divers livres sur l'intégration des immigrants en France]

Nouvel Observateur, no 1382, 2 mai , p. 68.1991

. [Compte rendu du livre "L'embarras de richesses : une interprétation de la culture hollandaise au siècle d'or" de S. Schama] Le Nouvel Observateur, no 1376, 21 mars, p. 701991

. [Compte rendu du livre "Spinoza et autres hérétiques" de Y. Yovel] Le Nouvel Observateur, no 1411, 21 nov. , p. 64. 1991

FURET, F. [Compte rendu du livre "Vychinski, le procureur de Staline : les grands procès de Moscou" de A. Vaksberg] Le Nouvel Observateur, no 1381, 25 avril , p. 62.1991

. [Compte rendu de divers livres sur Theodor Herzl] Le Nouvel Observateur, no 1436, 14 mai, p. 531992.

(et al.) La France éclatée Le Nouvel Observateur, no 1459, 22 oct. , p. 4-13.

1992

. La Ruine et les Restes. Le Débat, n 69, mars-avril, p. 1911992

. Concepts Juridiques et Conjoncture Révolutionnaire. Annales ESC, a. 47 p.

1185, 1992

. Les armes de Bill Clinton Le Nouvel Observateur, no 1461, 5 nov. p. 30-

35.1992

. [Compte rendu du livre "La prison républicaine" de R. Badinter] Le Nouvel

Observateur, no 1439, 4 juin, p. 54. 1992 
- L'Utopie démocratique à l'américaine Le Débat, n 69, mars-avril , p. 80

1992

. [Compte rendu du livre "Le grand recrutement" de T. Wolton] Le Nouvel

Observateur, no 1476, 18 févr. , p. 54. 1993

FURET, F e OZOUF, M. Fallait-il tuer Louis XVI? Le Nouvel Observateur, no 1471, 14 janv. , p. 4-11. 1993

FURET, F. La Chute Finale (entretien) L'Histoire, nº170, Paris, octobre 1993

. [Compte rendu du livre "La démocratie et les partis politiques" de M.

Ostrogorski] Le Nouvel Observateur, no 1489, 20 mai , p. 571993.

. [Compte rendu du livre "Le monde d'hier : souvenirs d'un Européen" de S.

Zweig] Le Nouvel Observateur, no 1477, 25 févr. , p. 54-55. 1993

. Aprés Robespierre, Staline... (Entretien) L’Histoire nº177 , Paris, mai 1994

. Pasternak, Jivago et le KGB Le Nouvel Observateur, no 1565, 3 nov. , p. 62.

1994

. Chronique d'une Décomposition. Le Débat, n 83, janv.-fév. , p. 84, 1995

. Nazisme et Communisme : la Comparaison Interdite (entretien) L'Histoire,

nº186, Paris, mars 1995

. Communisme-fascisme: comment naissent les dictatures. Le Nouvel

Observateur, no 1575, 12 janv. , p. 46-48 1995.

. [Compte rendu du livre "Correspondance générale" de J. Michelet] Le Nouvel

Observateur, no 1614, 12 oct. , p. 54-55. 1995

. [Compte rendu du livre "Cours au Collège de France" de J. Michelet] Le

Nouvel Observateur, no 1614, 12 oct. , p. 54-55. 1995

. [Compte rendu du livre "La tragédie soviétique : histoire du socialisme en

Russie" de M. Malia] Le Nouvel Observateur, no 1606, 17 août, p. 56.1995

.Le jeu était truqué Le Nouvel Observateur, no 1579, 9 févr. , p. 60-61. 1995

. [Compte rendu du livre "La fin de l'innocence : les intellectuels d'Occident et

la tentation stalinienne : trente ans de guerre secrète" de S. Koch] Le Nouvel

Observateur, no 1615, 19 oct. , p. 631995.

. DIEGUEZ, M. Dialogue sur la signification et la nature du communisme.

Commentaire, n 71, automne 1995. 
. (et al) François Mitterrand : une vie L'Express international, no 2323, 11 janv.

, p. 6-51. 1996

. Sur l'Illusion Communiste. Le Débat, n 89, mars-avril , p. 162, 1996

. Une Tragédie Américaine (entretien) L’Histoire, n¹97, Paris, mars 1996

. L'Amérique de Clinton II Le Débat, n 94, mars-avril, p. 31997

. L'Énigme Française, Le Débat, n 96, sept.-oct. , p. 43. 1997

FURET, F. Sur le multiculturalisme. Quelle culture ? Le Débat, nº 95, mai-août, p. 1871997

. [Compte rendu du livre "Louis Napoléon revisité" de A. Minc] Le Nouvel

Observateur, no 1681, 23 janv. , p. 62.1997

. De Platon à Heidegger : Tout, tout, tout sur la philosophie! Le Nouvel

Observateur, no 1689, 20 mars, 1997

. [Compte rendu du livre "Connaissez-vous Brunetière?: enquête sur un

antidreyfusard et ses amis" de A. Compagnon] Le Nouvel Observateur, no 1695, 30

avril , p. 62. 1997

. [Compte rendu du livre "Histoire de la Révolution d'Angleterre, 1625-1660" de

F. Guizot] Le Nouvel Observateur, no 1703, 26 juin , p. 54. 1997

IV - Obras de Referência

\section{A) Livros}

AGULHON, M. Histoire Vagabonde. 2vol. Paris, Editions Gallimard, 1988

. La République. Paris, Hachette, 2v, 1990

. (et. al.) 1789, La Commémoration. Paris, Gallimard, 1999

ANDERSON, P. A crise da crise do marxismo. Introdução e um debate contemporâneo. São Paulo, Brasiliense, 1984.

. Teoria, Política e História. Um Debate com E. P. Thompson. Madrid, Siglo

Veintiuno Editores, 1985.

. O Fim da História: de Hegel a Fukuyama. Rio de Janeiro, Zahar, 1992

.La pensée tiède: un regard critique sur la culture française. Paris, Seuil, 2005

ARENDT, H. Da Revolução. São Paulo, Ática, 1989

. O Sistema Totalitário. Lisboa, Dom Quixote, 1978 
ARON, R. As Etapas do Pensamento Sociológico. São Paulo, Martins Fontes, 1999 . Democracia e Totalitarismo. Lisboa, Presença, 1966 . O Ópio dos Intelectuais. Brasília, Editora UNB, 1980

BENJAMIN, W. Sobre o conceito da História. In. Obras Escolhidas. v.I São Paulo, Civilização Brasileira, 1985

BERGER, D. MALER, H. Une Certaine Idée du Communisme: Répliques à François Furet. Paris, Editions du Félin, 1996.

BETOURNE O. \& HARTIG A.I. Penser l'Histoire de la Révolution Française, Deux Siècles de Passion Française, Paris, La Découverte, 1989

BLACKBURN, R. (org) Depois da Queda: O fracasso do comunismo e o futuro do socialismo. Rio de Janeiro, Paz e Terra, 1992

BOBBIO, N. Direita e Esquerda: Razões e Significados de uma Distinção Política. São Paulo, Unesp, 1995 . O Filosofo e a Política: Antologia (Org. José Fernandes Santillán). Rio de Janeiro, Contraponto, 2003. . Os Intelectuais e o Poder: Duvidas e Opções dos Homens de Cultura na Sociedade Contemporânea. São Paulo, UNESP, 1997

BODEI, R. A filosofia do século XX. Bauru-SP, Edusc, 2000.

BOUTIER, J. JULIA, D. (org.) Passados Recompostos: Campos e Canteiros da História. Rio de Janeiro, UFRJ, 1998

BRAUDEL, F. História e Ciências Sociais. Lisboa, Editorial Presença, 1972.

BURGUIÈRE, A. (org.) Dicionário das Ciências Históricas. Rio de Janeiro, Imago Editora, 1993

BURKE, P. A Revolução Francesa da Historiografia: a Escola dos Annales: 1929-1989. São Paulo, UNESP, 1991.

CARDOSO, C. F. \& VAINFAS, R. (org.) Domínios da Historia: Ensaios de Teoria e Metodologia. Rio de Janeiro, Campus, 1997

CHAUVEAU, A. TÉTART, P. (orgs).Questões para a História do Presente. Bauru, SP, EDUSC, 1999.

CLAUDIN, F. A oposição no "socialismo real" União Soviética, Hungria, Polônia, Tchecoeslovaquia 1953/1980. Rio de Janeiro: Marco Zero, 1983.

COBBAN, Alfred. A Interpretação Social da Revolução Francesa. Lisboa, Gradiva, 1988. 
COCHIN, A. L'esprit du jacobinisme: une interpretation sociologique de la Revolution Française. Paris, PUF, 1979.

COMTE, A. Opúsculos de Filosofia Social. Porto Alegre/São Paulo: Globo/Universidade de São Paulo, 1972 Discurso sobre o Espírito Positivo. Porto Alegre/São Paulo, Globo/Universidade de São Paulo, 1976.

CORTÁZAR, J. Valise de Cronópio. Sao Paulo, Perspectiva, 2004

D’ALESSIO, M. M. Reflexões sobre o saber histórico: Entrevistas com Pierre Vilar, Michel Vovelle, Madeleine Rebérioux. São Paulo, Editora da Unesp, 1998.

DAHL, R. A. Análise Política Moderna. Brasília, Editora da Universidade de Brasília, 1981 DAHRENDORF, R. Após 1989: Moral, Revolução e Sociedade Civil. Rio de Janeiro, Paz e Terra, 1997

DARNTON, R. Os best-sellers proibidos da França pré-revolucionária. São Paulo, Cia das Letras, 1998

DOSSE, F. A História a Prova do Tempo: da História em Migalhas ao Resgate do Sentido. São Paulo, UNESP, 2001 A História em Migalhas: Dos Annales à Nova História. São Paulo: Ensaio, Campinas: Editora da Unicamp, 1992

DUMONT, J. Pourquoi nous ne Célébrerons pas 1789. Paris, Argé, 1987.

DUMOULIN, J. MOÏSI, D. (orgs) L'historien entre l'ethnologue et le futurologue. Paris, Mouton Éditeur, La Haye, 1972

ELTON, G. R. FOGEL, R. W. ¿Cuál de los caminos al pasado? Dos visiones de la historia. México, Fondo de Cultura Económica, 1989.

FERREIRA, M. M e AMADO, J. (orgs) Usos \& Abusos da História Oral. Rio de Janeiro, Editora FGV, 2000

FONTANA, J. História depois do fim da História. Bauru, SP, EDUSC, 1998. . História: Análise do Passado e Projeto Social. Bauru-SP, Edusc, 1998. A História dos Homens. Bauru-SP, EDUSC, 2004 .Para qué sirve la historia en um tiempo de crisis? Bogotá, Ediciones Pensamiento Critico, 2006

FRANK, R. Ecrire l'histoire du temps présent, en hommage à François Bédarida. Paris, CNRS éd.,1993 
FREUD, S. O futuro de uma ilusão. Rio de Janeiro, Imago Editora, 1997.

GARCIA P. Le Bicentenaire de la Révolution Française: Pratiques Sociales d'une Commémoration. Paris, CNRS Editions, 2000.

GERARD, A. A Revolução Francesa: Mitos e Interpretações. Editora Perspectiva, s/d.

GIOVAGNOLI, A. Storia e Globalizzazione. Roma, Editori Laterza, 2003

GINZBURG, C. O queijo e os vermes: o cotidiano e as idéias de um moleiro perseguido pela inquisição. São Paulo, Cia das Letras, 2002

GRAMSCI, A. Pasado y presente. Barcelona, Granica, 1977

HABERMAS, J. Mudança estrutural da esfera publica: investigação quanto a uma categoria da sociedade burguesa. Rio de Janeiro: Tempo Brasileiro, 1984

HEGEL, G. W. F. A Razão na História: introdução à filosofia da historia universal. Lisboa, Edições 70, 1995

Introdução à Historia da Filosofia. Col. Os Pensadores, São Paulo, Abril, 1974.

HELLER, A. Agnes Heller entrevistada por Francisco Ortega. Rio de Janeiro, EDUERJ, 2002.

. (et.al.) A crise dos paradigmas em ciências sociais e os desafios para o século XXI. Rio de Janeiro, Contraponto, 1999.

HELLER, A e FEHÉR, F. El péndulo de la modernidad: una lectura de la era moderna después de la caída del comunismo. Barcelona, Ediciones Península, 1994.

A Condição Política Pós-Moderna. Rio de Janeiro, Civilização Brasileira, 1998.

HUGHES-WARRINGTON, M. 50 Grandes Pensadores da História. São Paulo, Contexto, 2002

JUDT, T. Le Marxisme et la Gauche Française: 1830-1981. Paris, Hachette, 1987

JULIARD, J. WINOCK, M. Dictionnaire des intellectuels français, les personnes, les lieux, les moments. Paris, Ed. du Seuil, 1996

KAPLAN, S. L. Farewell, Revolution: the historian's feud: France, 1789/1989. London, Cornell University Press, 1995.

KAYE, H. Los Historiadores Marxistas Británicos, Universidad de Zaragoza, 1989

KOSELECK, R. Crítica e Crise: uma contribuição à patogênese do mundo burguês. Rio de Janeiro, Eduerj-Contraponto, 1999. 
KRIEGEL, A. Ce que j’ai cru comprendre. Paris, Laffont, 1991.

LADURIE, E. Le Roy. Entre los Historiadores. México, Fondo de Cultura Económica, 1989 . Paris-Montpellier, PC-PSU, 1945-1963. Paris Gallimard, 1982

LE GOFF, J. História e Memória. Campinas, Editora da Unicamp, 1992.

LE GOFF, J e NORA, P. (org.) História: Novos Problemas, Objetos e Abordagens. Rio de Janeiro, F. Alves, (3v), 1979.

LEFEBVRE, G. 1789: O surgimento da Revolução Francesa. Rio de Janeiro, Paz e Terra, 1989.

LEFORT, C. A Invenção Democrática: Os Limites do totalitarismo. São Paulo, Brasiliense, 1983

La Complication: Retour sur le Communisme. Paris, Fayard, 1999 . As Formas da História. São Paulo, Brasiliense, 1979

Pensando o Político: Ensaios sobre Democracia, Revolução e Liberdade. Rio de Janeiro, Paz e Terra, 1991.

LOPES, M. A. (org.) Grandes nomes da história intelectual. São Paulo, Contexto, 2003

LÖWI, M. Ideologias e Ciência Social: Elementos para uma Análise Marxista. São Paulo, Cortez, 1996

MAC MANNERS J., The Historiography of the French Revolution, The New Cambridge Modern History, t.VIII, chap. XXII, Cambridge, 1964

MALIA, M. La Tragédie soviétique. Histoire du socialisme en Russie, 1917-1991. Paris, Editions du Seuil, 1995

MARCUSE, H. Razão e Revolução: Hegel e o Advento da Teoria Social. Rio de Janeiro, Paz e Terra, 1978

MARX, K. O 18 Brumário e cartas a Kugelmann. São Paulo, Paz e Terra, 1997.

e ENGELS, F. A ideologia alemã. São Paulo, Grijalbo, 1977.

e ENGELS, F. A sagrada família ou crítica da crítica crítica contra Bruno

Bauer e consortes. Lisboa, Editorial Presença, s/d

MAZAURIC, C et. al. Debate Sobre a Revolução Francesa, In Textos Didáticos, ${ }^{\circ}{ }^{19}$, Campinas-SP, 1996

MAZAURIC, C. Sur la Révolution Française: contributions à l'histoire de la révolution bourgeoise. Paris, Éditions Sociales, 1970. 
Jacobinisme et révolution: autour du bicentenaire de Quatre-vingt-neuf. Paris, Éditions Sociales, 1984.

MAYER, A. J. The furies: violence and terror in the French and Russian Revolutions

Princeton, N.J.: Princeton University Press, 2000.

MORIN, E. Os meus demônios. Portugal, Publicações Europa-América, 1995

. Em busca dos fundamentos perdidos: textos sobre o marxismo. Porto Alegre, Sulina, 2002.

. (org.) A religação dos saberes: o desafio do século XXI. Rio de Janeiro,

Bertrand Brasil, 2002

NOLTE, E. Three faces of Fascism: Action Française, Italian facism, National Socialism.

New York/Chicago/San Francisco, Rinehart na Winston, 1966.

NOLTE, E.. Les Mouvements Fascistes: L'Europe de 1919 à 1945. Paris, Calmann-Lévy, 1991.

La guerra civil europea, 1917-1945 - Nacionalsocialismo y Bolchevismo.

México, Fondo de Cultura Econômica, 1994.

NETTER M.-L. La Révolution Française n’est pas Terminée. Paris, P.U.F, 1989.

NORA P. (org.). Les Lieux de Mémoire, t. I, Paris, Gallimard, 1984

ORY, P \& SIRINELLI, J-P. Les Intellectuels en France: de l'Affaire Dreyfus a nos Jours.

Paris, Armand Colin, 1992

PÉRRONET, M. A Revolução Francesa em 50 Palavras-chaves. São Paulo, Brasiliense, 1988

POCOCK, J. G. Linguagens do Ideário Político. São Paulo, Edusp, 2003

RÉMOND, R. Introdução a história de nosso tempo. São Paulo, Cultrix, 1976

. Notre siècle (1918-1991). Paris, Fayard, 1992.

. Por uma História Política. Rio de Janeiro, UFRJ:FGV, 1996

ROSANVALLON, P. O liberalismo econômico: história da idéia de mercado. Bauru,

EDUSC, 2002

SAMUEL, R. e STEDMAN JONES, G. (eds) Culture, Ideology and Politics: Essays for Eric Hobsbawm. Londres, Routledge \& Kegan Paul, 1982.

SARTRE, J-P. Em defesa dos intelectuais. São Paulo, Atica, 1994

SÈVE, L. Começar pelos Fins - a nova questão comunista. Porto, Campo das Letras Editores, 2001.

SIRINELLI, J-P. Intellectuels et passions françaises. Paris, Fayard, 1991 
. La France de 1914 à nos jours. Paris, PUF, ?

.Dictionnaire Historique de la vie politique française au XXe siècle. Paris, PUF, 1995

e RIOUX, .La guerre d'Algerie et les intellectuels français. Bruxelles, Ed.

Complexe, 1991

SOBOUL, A. A Revolução Francesa. São Paulo, Difel, 1974.

. A Revolução Francesa. Lisboa, Horizonte, 1979.

SOLÉ, J. A Revolução Francesa em Questões. Rio de Janeiro, Zahar, 1989

STONE, L. Causas da Revolucao Inglesa - 1529-1642. Bauru-SP, EDUSC, 2000

SWEEZY, P. (et al.) A Transição do Feudalismo para o Capitalismo: um debate. Rio de Janeiro, Paz e Terra, 1977.

TÉTART, P. Pequena História dos Historiadores. Bauru-SP, EDUSC, 2000

THANE, P, CROSSICK, G. e FLOUD, R. (eds). The Power of the Past: Essays for Eric Hobsbawm. Cambridge, Cambridge University Press, 1984.

TOCQUEVILLE, A. O Antigo Regime e a Revolução. Brasília, UNB, 1979

. A Democracia na América, São Paulo, Martins Fontes, 1998

VALÉRY, P. Variedades. São Paulo, Iluminuras, 1991.

VENTURI, F. Utopia e Reforma no Iluminismo. Bauru-SP, EDUSC, 2003

VOVELLE M. Combats pour la Révolution Française Paris, La Découverte, 2001 . Combates pela Revolução Francesa. (Edição Selecionada) Bauru: SP, EDUSC, 2004. . Jacobinos e Jacobinismo. Bauru-SP, EDUSC, 2000. . Michel Vovelle (entrevista em São Paulo), Bauru-SP, EDUSC, 2001

WALLERSTEIN, I. M. Após o Liberalismo: em busca da reconstrução do mundo. Rio de Janeiro, Vozes, 2002

\section{B) Artigos}

AGULHON, M. Pourquoi Célébrer 1789? L’Histoire, nº113, Paris, juillet/aout, 1988.

ASSOULINE, P. Eric Hobsbawm, de Marx a...Billie Holliday. Paris, L'Histoire, nº 100, 1987

BESANÇON, A. François Furet: une Pensée pour la Révolution. L'Express International, no 1945, 21 oct. 1988, p. 60-61. 
BIEN, D. D. Francois Furet, the Terror, and 1789. French Historical Studies, Vol. 16, No. 4 (Autumn, 1990). pp. 777-783

CHRISTOFFERSON, M. S. An Antitotalitarian History of the French Revolution: François Furet's "Penser la Revolution Française in the intellectual Politics of the Late 1970s. French Historical Studies, vol. 22, nº4, autumn 1999.

DANIEL, J. L'irruption totalitaire Le Nouvel Observateur, no 1582, 2 mars 1995, p. 50-53. DELORME-MONTINE, B. Intellectuels: um nouvel objet d'histoire. Le Débat, nº112, novdec 2000. p89 L'engagement démocratique. Le Débat, nº110, mai-out 2000

DOSSE, F. Pour une histoire intellectuelle sans dissimulation ni réduction. Le Débat, ${ }^{\circ} 73$, janv-fev 1993 p35

FELICE, R. de. La force de l’imprevu. Le Débat, n 89, mars-avril 1996. p120

FLORENZANO, M. Os Pés-de-Barro do Revisionismo. Novos Estudos, nº47, mar 1997

FLORENZANO, M. François Furet: Historiador da Revolução Francesa. Revista de História, nº132, São Paulo, FFLCH-USP,1995

. O impacto da Revolução Francesa na Inglaterra na década de 1790: história (Política) e historiografia. Pós-História: Revista de Pós-Graduação em História, UNESP, 2003

GALLO, M. "La République du centre" de François Furet, Jacques Julliard et Pierre Rosanvallon: du conformisme idéologique Le Monde diplomatique, no 415, oct. 1988, p. 29.

GREMION, P. Écrivains et intellectuels à Paris: une esquisse. Le Débat, nº103, janv-fév 1999 . L'Idée Communiste dans Notre Histoire Nationale: une Lecture de François Furet. Etudes sept. 1996, p. 207-217.

HALEVY, R. L’Idée et l’Événement. Sur les Origines Intellectuelles de la Révolution Française Le Débat, n³8 janv.-mars 1986

HALIME, S . La Mauvaise Mémoire de Pierre Nora. Le Monde Diplomatique, Juin 2005, p.35

HASSNER, P. François Furet et les passions du XXe siècle. Le Débat, nº107, 1999. p.137 HUARD, R. Hobsbawm: um regard aigu sur le $\mathrm{XX}^{\mathrm{e}}$ siècle. Regards, nº52, décembre 1999 JUDT, T. The Last Romantic. The New York Review of Books, New York, vol. 50, n. 18, nov 20, 2003. 
KERGOAT, J. La fin de la Fondation Saint-Simon vue par Jacques Kergoat. L'Humanité. 30 juin 1999.

KERSHAW, I. Nazisme et Stalinisme: limites d'une comparaison. . Le Débat, $\mathrm{n}^{\circ}$ 89, marsavril 1996. p177

KOTKIN, S. Left Behind: Is Eric Hobsbawm History? The New Yorker, New York, September 29, 2003. p 102-106.

LAIGNEL-LAVASTINE, A. L'Autre Europe et nous:dês années quatre-vingt aux années post-communistes. Le Débat, nº107, nov-dec 1999

LANGLOIS, C. François Furet : l'Atelier de la Révolution. Esprit, no 6, juin 1990, p. 12-21.

LARIN, J-P. L'Histoire de l'Idée Communiste au XXe Siècle selon F. Furet. Conjonctures, no 24, printemps 1996, p. 147-156.

LAURENT, V. Les Architectes du Social-Libéralisme. Le Monde Diplomatique, sep. 1998, p.1, 26-27.

LAZAR, M. Le Communisme em son Siècle. Critique, n588, Paris, mai 1996. p 361-372.

LEMIRE, L. De Lénine à Ziouganov: Y a-t-il un après-communisme? Le Nouvel Observateur, $n^{\circ} 1768$ - 24/9/1998

LEWIN. M. Illusion Communiste" ou Réalité Soviétique? Le Monde Diplomatique, no 513, déc. 1996, p. 18-19.

MANN, M. Alors que le XXe siècle se fait vieux. Le Débat, nº33, janv-fev 1997. p13

MARCOTTE, G. Liberté, égalité, fraternité. Liberté, no 183, juin 1989, p. 155-157.

MAZAURIC, C. Eric Hobsbawm, “J’ai abservé et ecouté et j’ai tente de comprendre l’histoire”. Journal l’Humanité. 15 décembre 2005.

MEIER, C. Um espoir voilé de crepe. Le Débat, nº93, janv-fev 1997. p36

MONTREMY, J-M. 1789.et 1793: la terreur en question L'Histoire, no 90, juin 1986, p.7274. . La Révolution Couronne François Furet. L'Histoire, no 120, mars 1989, p. 74-77 e GUENIFFEY, P. Robespierre, la Révolution et la Terreur. L'Histoire, no 177, mai 1994, p. 34-53.

MOSHER, M. On the originality of François Furet: A commemorative note. Political Theory, vol.26, n³, jun 1998. p 392-396. 
NICOLET, C. Faut-il larguer la République? Le Monde diplomatique, no 423, juin 1989, p. 20-21.

NOLTE. E. Sur la Theorie du Totalitarisme. Le Débat, n 89, mars-avril 1996, p. 139

NORA, P Traduire: necessite et difficultés. Le Débat, n93, janv-fev 1997. p93 François Furet dans Le Débat. Le Débat, n96, sep-oct 1997. p.7

OZOUF, M. Document: François Furet: lês feuilles mortes du communisme. L'Histoire, $\mathrm{n}^{\circ}$ 230, 1999

et al. Une Révolution sans Révolution? Le Nouvel Observateur, no 1112, 28 févr. 1986, p. 52-55.

. François Furet: Adieu. Le Débat, nº96, sep-oct 1997. p.4

PIPES, R Permanence de L’ Illusion. Le Débat, nº 89, mars-avril 1996, p. 147

POMIAN, K. La fin de l’histoire ne pas eu lieu. Le Débat. nº6, mai-aout 1990. p.258 Quel XXe siècle? Le Débat, n93, janv-fev 1997. p41

PROCACCI, G. De Plus loin et de Plus Pres Le Débat, n 89, mars-avril 1996, p. 153

ROBERT, J-L. Um itinéraire dans le siècle. Le Monde Diplomatique, Février 2006, p.21.

ROCHE, D. A chacun sa Révolution. Etudes, t. 369, sept. 1988, p. 197-209.

ROMAN, J. Commémorer la Révolution Française? Esprit, sept, 1989

ROSANVALLON, P. Gauche-droite: l'avenir d'une frontière Le Nouvel Observateur, no 1584, 16 mars 1995, p. 36-37.

La Fondation Saint-Simon, une histoire accomplie. Le Monde, Paris, 23 juin 1999.

SCHWARZ, B. Triomphe et tragédie du capitalisme. Le Débat, n93, janv-fev 1997. p76

SCOTT, W. François Furet and Democracy in France. The Historical Journal, vol. 34, nº1, mar 1991

SUTHERLAND, D. An assessment of the whitings of François Furet. French Historical Studies, vol. 16, nº4, fall 1990. p. 784-791.

TERRAY, E. Le Passé d'une Illusion et l'Avenir d'une Espérance. Critique, n588, Paris, mai 1996. p. 325-360.

VOVELLE, M. Michel Vovelle répond à le livre de François Furet, « Le Passé d'une Ilusion ». L’Humanité, 7 février 1995.

WINOCK, M. DOMENACH, N. Heurs et malheurs du socialisme français L'Histoire, no 170, oct. 1993, p. 40-62. 